\title{
The Hidden Value of Employee Pay Disclosures Evidenced through Cost of Capital
}

Christopher M. Sherman

Dissertation submitted to the faculty of the Virginia Polytechnic Institute and State University in partial fulfillment of the requirements for the degree of

\author{
Doctor of Philosophy \\ In \\ Business, Accounting and Information Systems
}

\author{
Ling L. Lisic (Chair) \\ Matthew J. Erickson \\ E. Scott Johnson \\ Marshall D. Vance \\ Jin $\mathrm{Xu}$
}

MARCH 17, 2020

Blacksburg, Virginia

Keywords: Voluntary Disclosure, Employee Pay Disclosure, Salary Expenses, Cost of Capital Copyright (C) 2020, Christopher M. Sherman 


\title{
The Hidden Value of Employee Pay Disclosures Evidenced through Cost of Capital
}

\author{
Christopher M. Sherman
}

\begin{abstract}
Voluntary disclosure theory suggests a firm increasing its disclosures should lower the information asymmetry component of its cost of capital. Empirical results on specific disclosures are mixed though, as individual disclosures may not provide enough value to investors in disclosure rich environments. Salary expense disclosures, unlike some other cost disclosures, may provide insight into increasing firm risk leading to an increased cost of capital, as employee pay has been shown to increase in response to leverage increases. I examine whether salary expense disclosures provide valuable information to investors, as measured through a disclosing firm's cost of capital, and I examine the channels through which the disclosure provides the information. I find that firms that disclose salary expense receive a lowered cost of capital if they are disclosing more stable cost structures, and the value of this disclosed information relates to the relative risk associated with the disclosed cost structures. I also find the propensity for firms to initiate disclosure increases as more analysts follow the firm and these initiating firms receive a lower cost of capital in exchange for their initial disclosure. Additionally, this lower cost of capital for initial disclosers is not based on the relative stability of the disclosed cost structure.
\end{abstract}




\section{The Hidden Value of Employee Pay Disclosures Evidenced through Cost of Capital}

Christopher M. Sherman

\section{GENERAL AUDIENCE ABSTRACT}

Theory suggests when a company voluntarily discloses information that is useful to investors, the investors will pay more for that company's stock which equates to a lower cost of capital for the company. Empirical results on individual disclosures are mixed though, as each disclosure may not provide enough value to investors in environments where companies disclose a large amount of information. Salary expense disclosures, unlike some other cost disclosures, may provide insight into increasing firm risk leading to an increased cost of capital for the disclosing companies, as employee pay has been shown to increase in response to leverage increases. I examine whether salary expense disclosures provide valuable information to investors, as measured through a disclosing firm's cost of capital, and I examine the channels through which the disclosure provides the information. I find that firms that disclose salary expense receive a lowered cost of capital if they are disclosing more stable cost structures, and the value of this disclosed information relates to the relative risk associated with the disclosed cost structures. I also find the propensity for firms to initiate disclosure increases as more analysts follow the firm and these initiating firms receive a lower cost of capital in exchange for their initial disclosure. Additionally, this lower cost of capital for initial disclosers is not based on the relative stability of the disclosed cost structure. 


\section{TABLE OF CONTENTS}

CHAPTER ONE - INTRODUCTION......................................................................................1

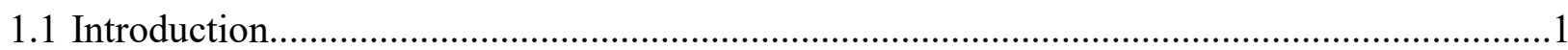

CHAPTER TWO - MOTIVATION AND HYPTOHESIS DEVELOPMENT...............7

2.1 Disclosures and Cost of Capital......................................................

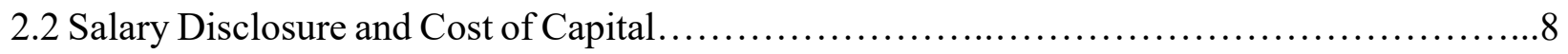

2.2a Potential for Insignificant Correlation between Salary Disclosure and Cost of Capital............8

2.2b Potential Negative Correlation between Salary Disclosure and Cost of Capital..................9

2.2c Potential Positive Correlation between Salary Disclosure and Cost of Capital...................10

CHAPTER THREE - RESEARCH METHODOLOGY ......................................12

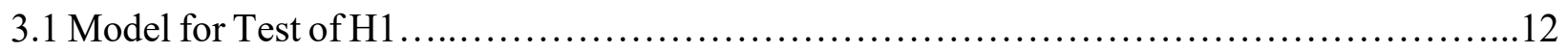

3.2 Entropy-Balanced Model..........................................................

CHAPTER FOUR - DATA AND SAMPLE SELECTION..................................17

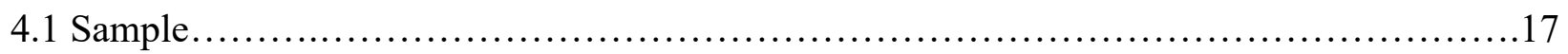

4.2 Descriptive Statistics and Univariate Tests......................................... 17

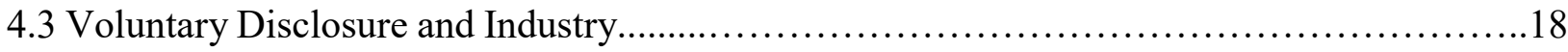

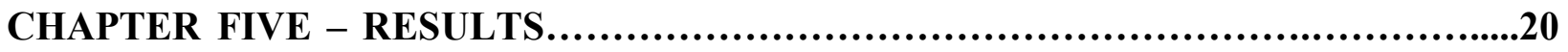

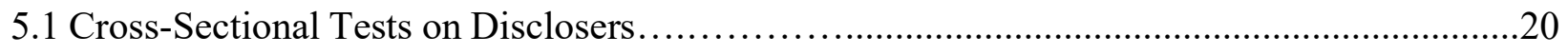

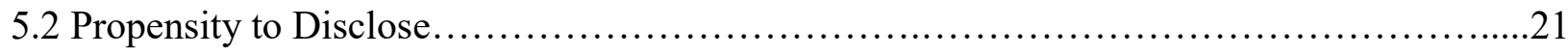

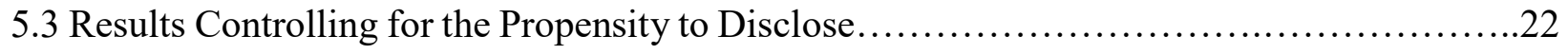

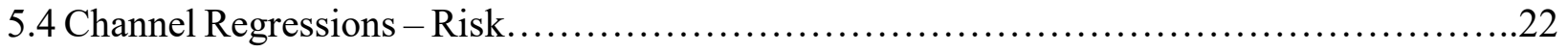

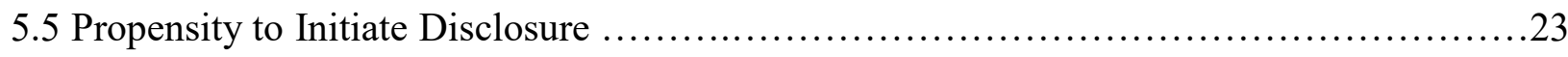

5.6 Results Controlling for the Propensity to Initiate Disclosure ............................24 
CHAPTER SIX - SUPPLEMENTAL ANALYSIS AND ROBUSTNESS...................26

6.1 Additional Cost of Capital Measures...........................................................................26

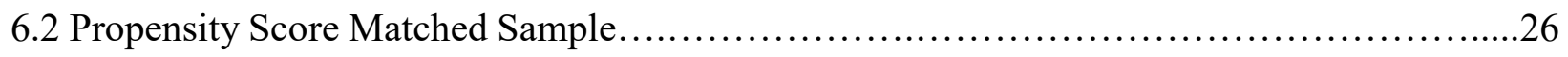

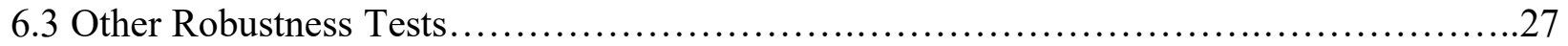

CHAPTER SEVEN - CONCLUSION...........................................................28

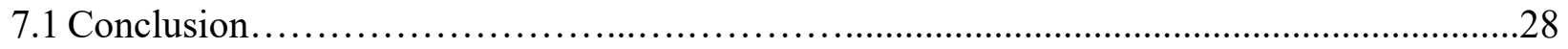

REFERENCES

TABLES..................................................................................32

APPENDIX A - VARIABLE DEFINITIONS......................................................44 


\section{LIST OF TABLES}

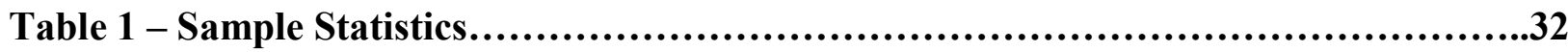

Panel A - Descriptive Statistics..........................................................

Panel B - Test of Means for VolDiscEmpPay ......................................... 32

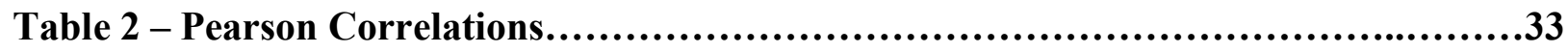

Table 3 - Count of Firms Initiating and Discontinuing Disclosure by Year...................34

Table 4 - Salary Expense Disclosure and a Firm's Cost of Capital...........................35

Table 5 - Propensity to Disclose................................................................36

Table 6 - Effect of Disclosure on Cost of Capital - Balanced Sample............................37

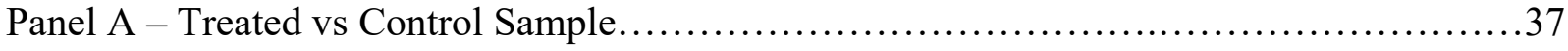

Panel B - Regression Results......................................................... 37

Table 7 - Why does Salary Matter? Salary as Indicators of Risk.............................38

Table 8 - Propensity to Initiate Disclosure......................................................39

Table 9 - Effect of Initiating Disclosure on Cost of Capital - Balanced Sample.................40

Panel A - Treated vs Control Sample ...................................................40

Panel B - Regression Results........................................................ 40

Table 10 - Salary Levels for Firms Initiating Disclosure....................................41

Table 11 - Multiple ICC Regressions for Robustness.......................................42

Table 12 - Effect of Initiating Disclosure on Cost of Capital - PSM Sample....................43

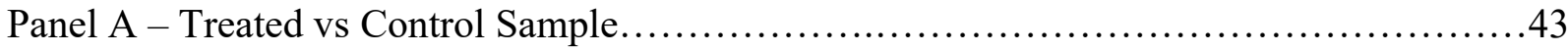

Panel B - Regression Results.......................................................43 


\section{CHAPTER ONE}

\section{INTRODUCTION}

\subsection{Introduction}

The prevailing theory of voluntary disclosure suggests that firms can voluntarily disclose

valuable information to reduce the information asymmetry between the firm and its investors and receive a reduced cost of capital in exchange for the reduced informational risk. However, theory related to salary expenses suggests that employees demand higher salaries if a firm increases its risk profile. Therefore, salary expense disclosures might lead to a higher cost of capital for the disclosing firm if the disclosure gives investors a view of increased risk. In this paper, I examine the impact of a firm's voluntarily disclosure of salary expenses (hereafter "salary disclosers") on a firm's cost of capital due, and the channels through which the disclosure provides information to investors.

Theory has shown that investors will discount the value of the firm's assets (through cost of capital) if important information is not disclosed by the firm (Grossman 1981; Milgrom 1981; Verrecchia 1983; Verrecchia 2001). Firms will disclose the information when the expected benefits of disclosure outweigh potential costs, leading to an ex ante prediction that firms disclosing specific information will have a lower cost of capital due to the disclosure (Beyer, Cohen, Lys, and Walther 2010). Yet in a disclosure rich environment this reduction is often muted, especially when examining individual disclosures, despite the information contained in the disclosure (Leuz and Verrecchia 2000). This has led to mixed empirical results. Salary expenses are unique from many other disclosures in that they may provide the employees' view of increasing firm risk to investors. Titman (1984) suggests that employees are risk averse and may demand higher salaries in exchange for working for a risky company. Consistent with this idea, 
Chemmanur, Cheng, and Zhang (2013) show that employee salaries rise in response to an increase in firm leverage. This view of increased risk has the potential to lead to an increased cost of capital for firms who disclose salary expenses, as opposed to the expected decrease in cost of capital for voluntary disclosures. Ultimately, it is an empirical question whether the cost of capital increases or decreases for salary expense disclosers.

I first examine whether a firm's cost of capital is associated with the disclosure of salary expenses, and I show in cross-sectional tests that salary disclosers (on average) have a higher cost of capital than non-disclosers, supporting the theory that salary expense disclosures provide valuable information regarding firm risk to investors. Additionally, my results show a firm's overall disclosure quality, separate from the disclosure of salary expenses, is negatively associated with its cost of capital, which is consistent with theory and prior literature.

I also examine both the salary expense itself (as a percentage of total operating costs) and the resulting average employee pay (disclosed salary expense divided by the number of employees), to determine whether both informational forms are valuable to investors. Salary expenses are unique from many other operating expenses in that they are relatively inflexible and stable (Berk, Stanton, and Zechner 2010), and a higher disclosed salary expense (as a percentage of operating costs) (hereafter "Salary") likely reflects a more predictable and stable cost structure, ${ }^{1}$ leading to an expected negative association between the expense and a firm's cost of capital. Chemmanur et al. (2013) find that average employee pay is positively associated with a firm's leverage, suggesting that employees respond to firm risk directly with a demand for increased

\footnotetext{
${ }^{1}$ As an extreme example, if salary expenses are more stable and predictable than other operating expenses, ceteris paribus, then a company with operating costs consisting solely of salary expenses would have a more stable and predictable cost structure than a company with no salary expense in their operating expenses.
} 
salaries. If this is true of other firm risk attributes as well, I would expect average employee pay to be positively associated with a firm's cost of capital.

My cross-sectional tests show a negative association between Salary and cost of capital but no association between average employee pay and cost of capital. These results suggest that investors use the salary disclosure to evaluate a firm's operating cost structure (and react accordingly), but the average employee pay is not significantly valuable to investors beyond available risk measures (leverage, etc.). Using this finding, I split salary disclosers above and below industry median Salary levels and show that firms disclosing lower than median levels of Salary are responsible for the positive relationship between salary disclosure and cost of capital, while firms with higher than median salary disclosures do not have a significantly different cost of capital than non-disclosers. ${ }^{2}$

These cross-sectional results do not fully examine the impact of disclosure itself though, because the choice to disclose could be due to a pre-existing high cost of capital, firm characteristics, or even investor pressure. I control for this choice by examining the factors associated with the propensity to disclose and then controlling for these factors in an entropy balanced sample (Hainmueller 2012). I first examine this for all salary disclosers' observations, then limit the tests to those initiating disclosure after not disclosing in the prior year. ${ }^{3}$ My tests for all disclosers show that firm characteristics and a high cost of capital (and not investor pressure) are associated with the propensity to disclose. ${ }^{4}$ I use an entropy-balanced sample balanced on these significant factors, I achieve covariate balance in my weighted samples, and I find a negative

\footnotetext{
${ }^{2}$ I follow the residual income methodology in Li and Mohanram (2014) to measure the cost of capital which averages results from Gebhardt, Lee, and Swaminathan (2001) and Claus and Thomas (2001)'s models. In robustness tests, I use additional cost of capital models with similar results.

${ }^{3}$ Only $19 \%$ of disclosing firms disclose after not disclosing in the prior year in my sample. The remaining disclose they first time they appear in my sample.

${ }^{4}$ As other studies have shown, the decision to disclose salary expenses is highly sticky, with only 5 of 1,089 firms choosing to stop disclosure and then restart.
} 
association between a firm's cost of capital and the disclosure of salary expense only for those firms who disclose a higher than industry median Salary. This supports the theory that firms voluntarily choosing to disclose of their own volition will receive a benefit if investors view the disclosed information positively, but disclosing information that investors do not view positively will not necessarily reduce your cost of capital.

I next examine the impact on cost of capital when a company first initiates disclosure by following the same methodology noted above, when I control for the factors associated with a company's propensity to initiate disclosure. This measures a change in disclosure policy and theory predicts a lower cost of capital for all initiating disclosers, or else they would not disclose this additional information (Beyer et al. 2010). I find that a larger analyst following (along with some firm characteristics) is a significant factor in the decision to initiate disclosure. I again use an entropy-balanced sample balanced on these significant factors, I achieve covariate balance in my weighted samples, and I find a negative association between a firm's cost of capital and disclosure of salary expense that is not dependent upon the level of Salary disclosed. This result supports the theory that when firms disclose due to a demand for increased information, they demand and receive a lower cost of capital in return.

Next, I explore the reasons investors might care about the level of a firm's Salary and salary disclosure in general. As mentioned above, salaries are generally stable, inflexible costs (Berk et al. 2010), and if a greater proportion of expenses are due to salaries, this could lead to more stable and predictable returns. My results show a negative association between Salary and a firm's return volatility, suggesting that salary expense disclosure can provide information regarding the stability of future returns. I additionally explore the association between the level of Salary and the volatility 
of operating expenses and show that firms with higher salary cost structures have a lower operating expense volatility.

My last tests examine how initiating firms react to investor feedback after disclosing salary expenses. I show that firms who initiate disclosure have a lower Salary on average in that initial disclosure year than other disclosers, and they subsequently adjust their cost structure to a Salary level on par with other disclosers (on average) by the third year of disclosure.

This paper contributes to current literature by showing that the disclosure of salary expense can provide valuable information to investors. The evidence indicates that investors prefer the predictable cost structures associated with high Salary and incentivize firms to adjust accordingly. This contributes to research that examines how investors use disclosure to monitor companies. Additionally, I extend research on the relationship between risk and employee salaries by providing evidence that the disclosure of employee salaries provide valuable information to investors due to the risk information that they contain.

I also show that investors will reward firms for disclosing when the firm is pushed for disclosure or when the disclosure contains favorable information, which has implications for mandatory disclosure rules. When Congress reacts to market failures by requiring new mandatory financial disclosures, such as the recent employee pay disclosure, ${ }^{5}$ there is often increased interest in whether they are simply trying to shame companies into compliance with their agenda or if the required disclosure has value to current and future investors (Murphy 1999; Murphy 2012). While other studies examine the potential effects of the new disclosure rule by examining the ratio of

\footnotetext{
${ }^{5}$ The Dodd-Frank Act, passed in response to the financial crisis of 2008, was signed into law July 21, 2010 with a requirement for the SEC to amend its reporting rules to include increased disclosure with regard to employee pay. This required disclosure, companies must disclose Median Employee Pay and the resulting CEO to Employee Pay Ratio, is in effect for annual reporting periods beginning on or after January 1, 2017.
} 
CEO to employee pay, my study provides insight on the employee pay portion of the disclosure. ${ }^{6}$

Because it is relatively common for Congress or the SEC to respond to economic incidents and populist outcries about unfair wages with new tax laws or disclosure requirements (Murphy 2012), ${ }^{7}$ many have argued that the employee pay disclosure shows Congress believes CEO pay is excessive and is trying to shame boards into lowering CEO pay through a pay ratio disclosure (Murphy 2012; Kelly and Seow 2016). ${ }^{8}$ Others, including the SEC (2015), claim employee pay is valuable information that current and potential investors should have available to them. My results provide support for this latter claim, but it also shows that the market is capable of obtaining information it requires (and rewarding firms accordingly) sans government intervention.

Section 2 presents the motivation and hypothesis development for my tests on the informational value of salary disclosures. Section 3 lays out the methodology of my tests while section 4 discusses the sample. Section 5 contains the main results that salary disclosure matter and explores the impacts of disclosing and potential reasons for the results. Section 6 contains robustness tests to show my results are not due to the choice of sample or methodology and Section 7 concludes.

\footnotetext{
${ }^{6}$ The disclosure of employee salaries provides similar information to that in the recent mandatory disclosure (Faleye, Reis, and Venkateswaran 2013)

${ }^{7}$ For example, in a 1930 takeover lawsuit, Bethlehem Steel was forced to disclose CEO and top manager bonuses and American Tobacco, in a shareholder lawsuit, was forced to disclose stock plan details (Wells 2010). This, along with other events led to the Securities Act of 1934 where the newly formed SEC required CEO pay disclosures. (Minor changes in CEO pay disclosures have become common and there have been major disclosure changes in 1978, 1993, 2006, and 2011.) In 1945, tax rulings on the effect of option pay led to restricted stock options and the ensuing awareness led to even more CEOs being paid in restricted stock than were paid in normal options prior to the tax rulings (Frydman and Saks 2010). A \$4.1m golden parachute for the CEO of Bendix in 1982 led to limitations on the tax deductibility of severance payments in 1984. The attention led to more golden parachutes for CEOs up to the deductibility limits (Alpern and McGowan 2001).

${ }^{8}$ While the initial drivers of the 2008 financial crisis were real estate financing related, large CEO and executive bonuses that were paid prior to the crisis made headlines as banks and other financial related institutions started to fail.
} 


\section{CHAPTER TWO}

\section{MOTIVATION AND HYPOTHESIS DEVELOPMENT}

\subsection{Disclosures and Cost of Capital}

The prevailing theory regarding disclosure is that information asymmetry causes an adverse selection problem in capital markets. Absent important information, rational investors will discount the value of the firm's assets or could even exit the market for that firm (Grossman 1981; Milgrom 1981; Verrecchia 1983; Verrecchia 2001). Disclosing information combats the information asymmetry issue both between managers and investors, and among investors, resulting in decreased volatility and a lower cost of capital. (Amihud and Mendelson 1986; Diamond and Verrecchia 1991). More information of a higher quality should lead investors to pay a higher price for capital. This can be a result of increased visibility stemming from a larger investor base across which to share risk (Merton 1987), reduced information asymmetry (among investors or between investors and managers) leading to reduced risk of trading on incomplete information (Verrecchia 2001), or higher quality disclosures reducing the risk of inaccurate investor estimates (Lambert, Leuz, and Verrecchia 2007). Absent any costs of disclosure, firms should disclose all private information investors are aware they possess in order to achieve the lowest possible cost of capital (Beyer et al. 2010). With regard to voluntary disclosure, firms will only disclose information if they expect investors (or other users) to provide a benefit that outweighs the potential costs of disclosure. Investors then cannot unilaterally assume withheld disclosure is "bad news", but can "discount the value of the firm such to the point the manager is better served to disclose" (Verrecchia 1983). ${ }^{9}$ As Bird and Karolyi (2016) note, the decision to disclose is not strictly an

\footnotetext{
${ }^{9}$ By extension, a demand for disclosure from investors has an implicit threat they might discount the value of the firm (increase cost of capital) unless the firm discloses the requested information. The discount is not required to precede the disclosure in order for it to be in response to investor demand.
} 
internal decision, as investors may increase a demand for disclosures. If a firm is reluctant to disclose bad information, but faces investor pressure to disclose, they may be facing two alternatives: refuse to disclose and let investors assume the worst case (increased cost of capital, reputational loss (Skinner 1994), etc.) or disclose the bad information and receive a reduced penalty. If investors do not perceive value in the information from that firm, or if the costs of disclosing are higher than the benefit investors will give a firm for their disclosure, a firm may not disclose.

Dhaliwal, Li, Tsang, and Yang (2011) argue this theoretical relationship between disclosures and cost of capital will apply only if the information disclosed is value-relevant. This lack of value relevance could be due to either the lack of value in the disclosed information itself or because investors view the information as less informative given a manager's incentives ${ }^{10}$ (Beyer et al. 2010). Despite the prevailing theories that disclosures should benefit firms, prior empirical evidence for the value relevance of individual disclosures (as measured through cost of capital) is mixed, especially in the disclosure rich environment of the United States (Leuz and Verrecchia 2000) where new disclosures provide only incremental informational content.

\subsection{Salary Disclosure and Cost of Capital}

\section{2a - Potential for Insignificant Correlation between Salary Disclosure and Cost of Capital}

It is unknown whether a salary disclosure by itself (separate from a firm's overall disclosure policy and quality) is value relevant enough for the benefits of disclosing to be manifest in a firm's cost of capital. Salary disclosures can potentially provide information in multiple ways. First, they can give investors information regarding levels of pay, such as total salary expense and average employee pay. However, for information to be valuable to investors and affect a change

\footnotetext{
${ }^{10}$ Managers have an incentive to disclose good news and hide bad news, thus a voluntary disclosure signals good news.
} 
to a firm's cost of capital, it must give investors additional insight into the future performance of a firm. It is not clear whether the disclosure of salary levels will provide significant information to investors beyond what operating or total expenses would provide. Second, salary disclosures can provide additional insight into the cost structures of a firm, which might provide more information to investors. However, absent a disclosure regarding salary expenses, financial statement users have used sales and administrative expenses as a proxy for salary levels (Awh and Primeaux 1985). Combined with industry knowledge, this proxy may allow investors to accurately predict a company's cost base to where a salary disclosure would not generally provide significant additional information to investors. For these reasons, an association between the disclosure of salary expense and a firm's cost of capital may not exist.

\section{2b - Potential Negative Correlation between Salary Disclosure and Cost of Capital}

Salary expense disclosures are a unique cost disclosure in that salary expense is highly persistent, as employees are entrenched and the costs do not typically change substantially due to employee entrenchment (Berk et al. 2010). Therefore, this disclosure may provide a more predictable view of costs that proxies cannot provide. Additionally, the SEC has stated that the disclosure of employee pay and the resulting pay ratio will give investors insight into appropriate levels of CEO compensation (SEC 2015). If this is the case, it implies there is significant value in the voluntary disclosure of salary costs, as they can be used to measure the average employee pay and pay ratio.

Firms will only initiate disclosure if the benefit exceeds the cost of disclosing, and prior research suggests salary disclosure may carry a high cost. Depoers (2000) finds that managers withhold information when the information may compromise a firm's competitive advantage or increase labor pressures (i.e., disclosure of employee salary information can increase demand for 
higher wages by lower paid employees). Workers paid below the disclosed average/median amount may also have lower job satisfaction when that information is known (Card, Mas, Moretti, and Saez 2012), ultimately reducing the firm's performance. With a potentially high cost of disclosing salary information, I expect the benefit to disclosing firms to be significant to compensate for the potential disclosure costs. If these arguments hold, I expect firms who disclose to have a lower cost of capital than non-disclosers, ceteris paribus.

\section{2c - Potential Positive Correlation between Salary Disclosure and Cost of Capital}

Recent research suggests employee wages can tell investors a great deal more than the basic cost base structure. Faleye et al. (2013) examine pay ratios for S\&P 1500 firms who disclose salary expense and show that firm value and operating performance both increase with relative pay, with employees viewing the large gap between their pay and executive pay as an opportunity. Employees are also known to have inside information about future firm performance (Babenko and Sen 2015). This suggests employees have specialized firm knowledge that could be valuable to investors.

Unlike most operating costs, salary expenses are the result of negotiations between the employee and employer, with both parties having access to inside information. Employees, who rely on the company for their livelihood, are naturally risk averse and may demand a premium when working for a risky firm (Titman 1984; Berk et al. 2010). Chemmanur et al. (2013) empirically show that average employee pay rises when firms take on more risk (leverage), as employees demand an offset to the additional bankruptcy risk of the company. Employees are likely to pay attention to their employer's policies affecting firm risk given the potential impact to them personally. Thus, a disclosure of salary expense could be a significant source of insider information as changes to salaries over time may reflect firm risk beyond mandated disclosures or 
traditional accounting measures. This could result in a positive relationship between salary disclosures and a firm's cost of capital.

Since the decision to disclose is often a longer-term decision, the cost of capital impact upon initial disclosure may be different than the longer-term impact. This may be the case for salary expenses in particular because salaries may respond to changes in firm risk (Chemmanur et al. 2013). Given the competing theories regarding the directional impact on a firm's cost of capital from the disclosure of salary expenses, as well as this timing question, the following hypothesis is in null form.

H1: Salary expense disclosures are not associated with cost of capital. 


\section{CHAPTER THREE}

\section{RESEARCH METHODOLOGY}

\subsection{Model for Test of $\mathbf{H 1}$}

To test H1, I use the following model to examine the effect of salary disclosures on a firm's cost of capital (AvgRI):

$$
\begin{aligned}
{\text { AvgRI }=\beta_{0}} & \beta_{1} \text { Disclosure }_{i, t}+\beta_{2} D Q_{i, t}+\beta_{3} \text { BTM }_{i, t}+\beta_{4} M V E_{i, t}+\beta_{5} \text { swbeta }_{i, t} \\
& + \text { FirmFundamentals }_{i, t}+\text { Industry } F E+\text { Year } F E+\varepsilon i_{t}
\end{aligned}
$$

For my cost of capital variable, I follow Li and Mohanram (2014) who combine the crosssectional methodology of (Hou, van Dijk, and Zhang 2012) (HVZ) with the two extant residual income models (Gebhardt et al. (2001) (GLS) and Claus and Thomas (2001)(CT)) to provide an updated implied cost of capital model that is not limited by analyst forecasts. As recommended by Li and Mohanram (2014), my main cost of capital variable (AvgRI) is the average of these two residual income models. The benefit of this measure is that it uses the prior 10 years of data in the cross-sectional model to generate forecasts, which are used to determine the implied cost of capital. Other cost of capital measures rely on analyst earnings forecasts which can be optimistically biased given the analysts' conflict of interests (Lin and McNichols (1998); McNichols and O'Brien (1997)) and can lead to large valuation errors in the resulting models (Abarbanell and Bushee 1997). Additionally HVZ's methodology eliminates the need for analyst data which would exclude a large number of firms in my sample, particularly small or financially distressed firms (Hou et al. 2012).

My main Disclosure variable is an indicator variable equal to 1 if a firm discloses salary expense $^{11}$ in that year, and 0 otherwise (VolDiscEmpPay), to examine whether the disclosure of

\footnotetext{
${ }^{11}$ Disclosure of salary expense is measured using the Compustat variable XLR. It typically includes all personnel expenses such as wages, pension and other direct benefits.
} 
salary expenses has an effect on a firm's cost of capital. Leuz and Wysocki (2016) note the need to control for overall disclosure quality when examining voluntary disclosures, as disclosure decisions are often made with regard to overall disclosure policies. Many recognized disclosure quality measures rely on biased sources that are often available only for large firms (analyst ratings in AIMR scores), are subjective and narrative (measures based on conference calls, management forecasts, and MD\&A), or self-constructed by researchers for their use (Chen, Miao, and Shevlin 2015; Leuz and Wysocki 2016). In response, Chen et al. (2015) developed an overall disclosure quality measure based on non-missing Compustat items that can be calculated for all firms/years with data available. I follow their methodology to calculate overall disclosure quality (DQ) and their overall model for calculating the impact of disclosure on the cost of capital. ${ }^{12}$ Because their methodology takes into account whether a firm discloses salary expense in the DQ calculation, I exclude the effect of a firm's salary disclosure decision from my calculation to isolate the effect separately in my model.

Additional cost of capital controls include book to market (BTM) which controls for the firm's overall value, market value of equity (MVE) which controls for firm size, and CAPM beta estimated using the Scholes-Williams method (swbeta) which controls for firm risk. These are standard controls for cost of capital models (Chen et al. 2015; Dhaliwal et al. 2011; Li and Mohanram 2014). In addition, I control for additional firm fundamentals as recommended by Chen et al. (2015). ${ }^{13}$

\footnotetext{
${ }^{12}$ The cost of capital is calculated as of the quarter following time t's year-end.

${ }^{13}$ Firm fundamentals controlled for are whether a firm has restructuring costs (Restructure), Special items amount (si), Std Dev of a firm's returns (sdret), and the number of business segments (NSEG). See Appendix 1 for a full list of variables and definitions.
} 
By nature, any voluntary disclosure decision suffers from selection bias. To address this, I use an entropy-balanced sample to control for this selection by matching/balancing on determinants of the decision to disclose.

\subsection{Entropy-Balanced Model}

To create balanced samples, I first examine determinants of the propensity to disclose salary expense for the firm using a logistic model. Because the disclosure of salaries is part of a firm's overall disclosure policy, I identify potential determinants from both voluntary disclosure literature and salary literature that may be related to the decision to disclose.

$$
\begin{aligned}
& \quad \text { Decision }=\beta_{0}+\beta_{1} \text { MVE }_{i, t}+\beta_{2} \text { BTM }_{i, t}+\beta_{3} D_{i, t}+\beta_{4} \text { AvgRI }_{i, t}+\beta_{5} \text { ROA }_{i, t}+ \\
& \beta_{6} \text { IndConcentration }_{i, t}+\beta_{7} \text { MktLev }_{i, t}+\beta_{8} \text { CapRaised }_{i, t}+\beta_{9} \text { InstOwnership }_{i, t}+ \\
& +\beta_{10} \text { PCI }_{i, t}+\beta_{11} \text { Union }_{i, t}+\beta_{12} \text { AnalystDisp }_{i, t}+\beta_{13} \text { AnalystCoverage }_{i, t}+ \\
& \beta_{14} \text { AnalystCoverage }_{i, t}+\text { Ind }+Y r+\varepsilon i_{t}
\end{aligned}
$$

My tests examine the effect of disclosure in any particular year as well as the effect of the initial decision to disclose. The dependent variable (Decision) for the main test is VolDiscEmpPay and for the initial decision to disclose is NewVol (an indicator variable that equals 1 if a firm initiates disclosing salaries in a year after not disclosing in the prior year, and 0 for all firm observations for firms that do not ever disclose in my sample). The model includes industry and year indicators and all standard errors are corrected using the Huber-White procedure.

Theory suggests a firm could disclose due to internal decisions, such as a desire to lower cost of capital, or due to investor pressures, with investors looking to better understand firm risk through increased information. I control for overall disclosure quality (DQ) in the current year as disclosure decisions are often made as part of an overall disclosure policy (Chen et al. 2015). I 
include MVE for a firm's size as a potential determinant because size has been shown to be associated with increased disclosure (Lang and Lundholm 1993). I control for value (BTM) as a potentially over/under-valued firm may face pressure to disclose more to justify its current value.

I include the firm's prior year cost of capital (AvgRI) as a potential determinant as theory says a firm may disclose additional information to decrease an already high cost of capital (Dhaliwal et al. 2011). I include performance (ROA) as it can affect a whether a firm discloses additional information as theory suggests investors may not push for as much information for higher performing firms. As mentioned above, a firm's competitive environment may influence the cost of salary disclosures, so I include industry concentration (IndConcentration) as measured by the Herfindah-Hirschman Index with an ex ante expectation that highly concentrated industries will disclose more due to the lower competitive cost of disclosure. Theory also suggests that higher levels of leverage (MktLev) may cause debt holders to demand a greater monitoring role through increased disclosure. Relatedly, I also include recent capital increases (CapRaised) as firms with recent capital raises are likely to face increased demand for disclosures. Because investors may influence a firm's disclosure policy through additional demands, I include the level of institutional ownership (InstOwnership).

I include physical capital intensity (PCI) as a proxy for employee skill level. Firms dependent upon more highly skilled labor could have a greater percentage of costs related to salaries and could face greater pressure to disclose those costs than firms less reliant on skilled labor. I also include the percentage of industry employees covered by a collective bargaining agreement (Union) (Hirsch and Macpherson 2003), which could decrease additional disclosure as much of the information may be disclosed through the union (Faleye et al. 2013). Finally, I add three analyst measures potentially related to investor demand for additional information: the 
dispersion of analyst forecasts (AnalystDisp), level of analyst coverage (AnalystCoverage), and the average error of analyst forecasts (FcastError). Forecast dispersion and errors could increase the demand for more information to better predict future results, and the level of analyst coverage could positively affect the demand for information due to increased analyst competition. ${ }^{14}$

\footnotetext{
${ }^{14}$ I use time $t$ as there is little change year to year for the decision to disclose salary expense. For the logit model on the decision to initiate disclosure, I use time t-1 for all of the variables except DQ, Institutional Ownership, and Analyst Coverage as any changes to these variables from the prior year may be correlated to the decision to initiate disclosure.
} 


\section{CHAPTER FOUR}

\section{DATA AND SAMPLE SELECTION}

\subsection{Sample}

I start with all 130,229 NYSE, Amex, and Nasdaq listed securities observations from the CRSP/Compustat merged database with share codes 10 or 11 (i.e. excluding ADRs, closed-end funds, and REITs) from $1984-2018,{ }^{15}$ excluding utilities and financial firms. ${ }^{16}$ For this sample, I can calculate AvgRI for 92,646 observations. I drop an additional 9,262 observations due to missing monthly return, business segment, or beta information for a final sample of 83,384 observations from $1984-2018$.

\subsection{Descriptive Statistics and Univariate Tests}

Disclosing firms account for 6,127 firm year observations (7.3\% of total) and are on average larger and less risky. They also have a lower overall disclosure quality than non-disclosing firm observations. Firms who choose to disclose at any point in my sample (1,089 firms) disclose salary expense (on average) for 5.6 of their 9.2 years in the sample. Additionally, 607 firms (56\%) disclose for all years they appear in my sample, and 212 firms initiate disclosure after previously not disclosing. Of the 1,089 firms who disclose, 270 (25\%) stop disclosing at some point in the sample ${ }^{17}$ and only 5 disclosing firms stop disclosing and then restart at a later date. This suggests salary disclosure is a deliberate long-term choice, not simply a part of an overly generous disclosure policy, and firms do not choose which years to disclose based on the annual salary expense levels.

\footnotetext{
${ }^{15}$ The statement of cashflows became mandatory in 1987. My results are robust to the exclusion of $1984-1986$.

${ }^{16} \mathrm{DQ}$ would not be applicable to these industries as they have different disclosure standards than other industries.

${ }^{17}$ In untabulated results, I find firms who stop disclosing have a significantly lower Salary and do not (on average) receive a lower cost of capital due to the disclosure, which may be the reason they decide to discontinue disclosing the information.
} 
Univariate Tests show a negative relationship between AvgRI and both Salary (salary expense divided as a percentage of total operating expenses) and AEP (average employee pay), suggesting investors reward companies who control salary costs. As expected, firms who are $\operatorname{larger}^{18}$ and those with higher disclosure quality (DQ) enjoy a lower cost of capital. I also find a negative relationship between risk (swbeta) and cost of capital which, while contrary to conventional wisdom, coincides with the results in Li and Mohanram (2014). ${ }^{19}$

\subsection{Voluntary Disclosure and Industry}

Faleye et al. (2013), while limiting their sample to S\&P 1500 firms, note that voluntary disclosers may be concentrated in some industries. To explore this further, I split industries by the percentage of disclosing observations in that industry (split above and below the median percentage). High disclosing industries contain over $83 \%$ of the disclosing observations compared to $51 \%$ of the total observations. On average, the firms (all firms, not just salary disclosers) in these industries have a higher AvgRI than firms in other industries, which is consistent with firms disclosing in an attempt to reduce their cost of capital. Salary disclosers in these industries have a higher percentage of costs in salary expense and a lower average salary than salary disclosers in other industries. They are, on average, smaller firms in less competitive industries with a higher level of disclosure quality than disclosers in other industries have. Transportation and transit firms (SIC 40xx - 47xx) and service firms (SIC 8xxx) have the highest disclosure rates at $26.6 \%$ and 19.4\% respectively. Within the service firms, health services (SIC 80xx) and social services (SIC $83 \mathrm{xx}$ ) have high disclosure rates of $31.9 \%$ and $20.5 \%$ respectively. At the other extreme, Apparel

\footnotetext{
${ }^{18}$ Total assets and MVE are correlated above the .9 level. This is consistent with the findings of (Chen et al. 2015) and is the reason I do not include assets as a size variable in my multivariate tests, instead relying on MVE.

${ }^{19}$ The same negative relationship shows up in my multivariate tests, consistent with Li and Mohanram (2014). (See Monahan and Easton (2010) for a discussion of ICC metrics and conventional risk.)
} 
and Leather Product industries (SIC 23xx and SIC 31xx respectively) have no salary disclosers despite comprising almost $1.7 \%$ of the sample..$^{20}$

${ }^{20}$ Given the disparate tendency to disclose depending on the industry, my multivariate tests include both Industry and Year FE and clustered standard errors for both the year and either the industry or firm. This is consistent with prior literature. 


\section{CHAPTER FIVE}

\section{RESULTS}

\subsection{Cross-Sectional Tests on Disclosers}

Table 4 examines the effects of the disclosure of salary expenses on the discloser's AvgRI. Model 1 utilizes the full sample and shows a positive correlation between firm observations that include a salary disclosure (VolDiscEmpPay=1) and a firm's AvgRI. On average, a disclosing firm has a $.7 \%$ higher cost of capital than non-disclosing firms. This suggests that investors are receiving valuable information from the disclosure that they are using to value the firms. The coefficients on all of my control variables (except Restructure) are significant and in the same direction as prior research.

I next explore the informational channels through which investors utilize the disclosure. When a firm discloses salary expenses, they are not disclosing additional direct information regarding firm profitability, which is already provided through total costs. However, they are disclosing information regarding cost structures of the firm, given the unique nature of salary expenses compared with other expenses, along with average pay levels within the firm. ${ }^{21}$ I regress AvgRI on these two measures to examine whether investors value the disclosure because it provides information about the firm's cost structures (Salary) or because it indicates how much they pay the average employee (AvgPay). The results in model 2 of Table 4 show a negative correlation between Salary and cost of capital. In economic terms, a one standard deviation increase in Salary at the average would move a firm from an $8.1 \%$ to a $7.8 \%$ cost of capital. Model 3 does not find an association between AvgRI and average employee pay (AvgPay). ${ }^{22}$ To further

\footnotetext{
${ }^{21}$ Results on Salary and AvgPay are robust to the exclusion of CEO salary expenses (untabulated).

22 These results suggest the recent mandatory disclosure of median employee pay does not contain valuable information to investors apart from CEO to employee pay ratio disclosures.
} 
examine the effect of salary disclosure on a firm's cost of capital, I split disclosing firms into those disclosing salaries that are above and below the industry median Salary. Models 4 and 5 recreate the results in model 1 with disclosing observations split (those with low Salary in model 4 and high Salary in model 5). The results indicate firms who disclose Salary below the industry median cause the positive association of salary disclosure with cost of capital that I find in the overall sample. ${ }^{23}$ Combined, the evidence suggests investors receive valuable information from salary expense disclosures for the purpose of understanding cost structures but do not value information related to the salaries individual workers are paid. Given the inflexible nature of salaries (Berk et al. 2010), it appears investors prefer companies with more predictable cost structures.

\subsection{Propensity to Disclose}

The decision to disclose salaries is voluntary and the results above may be endogenous to the factors that incentivize a firm to disclose. As mentioned earlier, firms should voluntarily disclose and expect a benefit if the disclosed information is viewed favorably by investors. Another influence on whether a firm discloses is if investors demand new information (Bird and Karolyi 2016). My initial results indicate that firms have a higher cost of capital if they disclose a lower than industry median Salary. However, this does not take into account the factors that may lead a firm to disclose. To correct for this selection bias, I examine the factors potentially associated with the decision to disclose in Table 5 and then control for the decision determinants in later tests.

Table 5 regresses the disclosure of salary expense on the potential determinants identified in Section 3.4. The results show that larger, lower-valued (higher BTM) firms with low disclosure quality and high cost of capital are more likely to disclose. None of the analyst variables are significantly correlated with disclosure suggesting the disclosure decision is (on

\footnotetext{
${ }^{23}$ Additionally, the coefficients for low and high Salary firms are significantly different based on Chi-squared tests of coefficient equality (.0042).
} 
average) driven by the firm. Firms with highly skilled (PCI) employees and employees more likely to be part of collective bargaining agreements (positive coefficient on Union) are also more likely to disclose.

\subsection{Results Controlling for the Propensity to Disclose}

To control for the endogenous choice to disclose salary expenses, I create an entropybalanced sample using the significant determinants identified in the results of the logit model above (MVE, BTM, DQ, AvgRI, PCI, and Union). The results in panel A of Table 6 show that the treated and control samples are successfully balanced on all of the determinant variables. The results for the regressions using these balanced samples (Table 6, panel B) show that firms that disclose do not on average have a significantly different cost of capital than non-disclosers with similar firm characteristics on average (model 1). However, results in Table 4 show that investors value the information contained in salary expense disclosures with a preference for higher Salary. When I split the disclosers between Low Salary (model 2) and High Salary (model 3) disclosers, I show that investors do reward High Salary disclosers with a lowered cost of capital. This supports the theory that firms who voluntarily disclose information that investors view positively can expect a lower cost of capital. Interestingly, I do not find that firms who choose to disclose information that is not positively viewed are penalized through cost of capital for revealing that information.

\subsection{Channel Regressions - Risk}

Given the overall negative correlation between Salary and cost of capital, I next explore whether the disclosed salary expense provides additional information regarding risk to investors, as theory suggests. If investors value higher Salary (previous results show an inverse relationship between Salary and AvgRI) because salary expenses are more stable (Berk et al. 2010), then Salary should be inversely related to the volatility of both a firm's operating expenses and returns. In 
Table 7, I regress return volatility (ret_sd) on Salary for all disclosers (Model 1) and for both Low Salary and High Salary firms (models 2 and 3 respectively). I find a negative association between Salary and risk for the full sample and for the Low Salary firms, but not for High Salary firms. This provides additional evidence that investors receive information regarding firm risk from the Salary disclosure and that this risk may be why Low Salary disclosers do not receive a cost of capital benefit when they voluntariy disclose without analyst or investor pressure. In ModelsI follow Dhaliwal, Lee, Pincus, and Steele (2017) and Kothari, Li, and Short (2009)'s models for my control variables. These standard risk controls are the BTM (natural log), MVE, leverage (lev), and standard deviation of operating cash flows (CFlow_sd). I also include firm return skewness over the prior year (ret_skewness), average daily share turnover (vol_mean), and the stock return excluding dividends for that year (retx_sum) for return volatility specific controls.

\subsection{Propensity to Initiate Disclosure}

As mentioned in Section 4, the majority of firms disclose for all observations in my sample. I next examine the effects on a firm's cost of capital due to the decision to initiate disclosure for those firms who initiate disclosing at some point in my sample after not disclosing, controlling for the propensity to initiate disclosure. These are firms who choose to change their salary expense disclosure policy and, if our prior results showing the disclosure has valuable information are valid, theory would suggest we should see a decrease in cost of capital for these new disclosers at the time of this change in policy.

Table 8 regresses the initiation of salary expense disclosure on the potential determinants identified in Section 3.4. The results show that firms with a larger number of analysts (AnalystCoverage) and lower performance (ROA) are more likely to initiate disclosure. This suggests an environment where there is pressure for increased information to better monitor 
these firms and to understand their costs. Alternatively, prior AvgRI is not a significant factor in firm decisions suggesting that firms are not initiating the disclosure on their own to reduce an abnormally high cost of capital. Firms with highly skilled (PCI) employees and employees less likely to be part of collective bargaining agreements (negative coefficient on Union) are also more likely to initiate disclosure. These results fit with the theory that firms initiate disclosure due to outside pressure, and I would anticipate finding a reduced cost of capital for firms initiating disclosure.

\subsection{Results Controlling for the Propensity to Initiate Disclosure}

To control for the endogenous choice to disclose salary expenses, I create an entropybalanced sample using the significant determinants identified in the results of the logit model above (ROA, AnalystCoverage, PCI, and Union). The results in panel A of Table 9 show that the treated and control samples are successfully balanced on all of the determinant variables. The results for the regression using these balanced samples (panel B, model 1) show that firms who initiate disclosure have a lower cost of capital than non-disclosers (after controlling for the choice to disclose). This is true for both Low Salary (model 2) and High Salary (model 3) initiators. This result provides evidence for theory that suggests firms will voluntarily disclose based on the demand for increased information in exchange for a reduced cost of capital. ${ }^{24}$

The results so far show that investors prefer a firm to have a higher Salary (ceteris paribus) since firms with a high Salary have a lower AvgRI (Table 6). I next examine whether firms react

\footnotetext{
${ }^{24}$ In untabulated tests, I recreate these tests for firms who stop disclosing after previously disclosing in my sample. I find larger firms in highly competitive industries with highly skilled labor are more likely to stop disclosing. Utilizing entropy-balanced samples, I find these firms have an increase in cost of capital compared to non-disclosing firms. This result is consistent with theory that suggests there are potential competitive costs to disclosing salary information and firms may decide to not disclose if the benefit does not outweigh the higher costs.
} 
to this preference by examining the Salary level for initiating firms in the year of initial disclosure compared to other disclosing firms and their own future disclosures in Table 10.

Untabulated univariate results suggest that firms who initiate disclosing in my sample (NewVolFirms) have a $4 \%$ lower Salary (1.5 percentage points, significant at the $10 \%$ level) than other disclosing firms (firms who voluntarily disclose in all years that they are in my sample). Regression results in Table 10 show NewVolFirms (model 1) do not have a significantly different Salary on average than other disclosing firms. In the regressions, I follow Chemmanur et al. (2013) and control for size (MVE), average sales per employee (AvgSales), market to book (MTB), and the physical capital intensity of the firm (PCI). I also control for both EBIT and the standard deviation of EBIT to hold profitability and its volatility constant. Model 2 compares the initial Salary disclosure for NewVolFirms compared to the disclosed Salary for other firms and I find that the initial disclosed Salary is significantly lower than other firm's disclosures. Combined, these results suggest that firms who initiate the disclosure have low initial Salary levels, but adjust them up over time (no difference in Salary levels on average). I confirm this result in models 3 and 4 by comparing the Salary of the initial disclosed year for initiators with their Salary in future years (time $t+1$ and $t+2$ respectively). I find that the initial Salary is significantly lower at the time of initial disclosure than in year $\mathrm{t}+1$ and $\mathrm{t}+2$ suggesting that firms make a structural shift over the first 2 years of disclosure in response to investor feedback. 


\section{CHAPTER SIX}

\section{SUPLEMMENTAL ANALYSIS AND ROBUSTNESS}

\subsection{Additional Cost of Capital Measures}

My main cost of capital measure is the average of two residual income models as recommended by Li and Mohanram (2014). To ensure that my results are not dependent on the chosen model, I replicate the main results in Table 4 with four individual cost of capital measures. ${ }^{25}$ In addition to my main cost of capital measure (AvgRI), I use the two individual residual income measures on their own, based on Gebhardt et al. (2001) and Claus and Thomas (2001)'s models as well as a measure based on Ohlson and Juettner-Nauroth (2005) and a simplified price earnings growth model (Li and Mohanram 2014). All four individual models show results consistent with those in Table 4. In addition, I show consistent results for the firm control variables in the expected direction suggesting that my results do not rely on a particular cost of capital model.

\subsection{Propensity Score Matched Sample}

In Table 11, I use entropy balancing to control for the selection bias in the choice to disclose. Table 14 shows results using a propensity score matched sample for initiating disclosers. ${ }^{26}$ I use a caliper distance of .05 and the two nearest neighbor matches for the PSM matching, but accuracy and results are similar for multiple other caliper and control matching settings.

The matching results (panel A) show that the propensity score matching was successful, with no significant differences remaining on AnalystCoverage, PCI, or Union. Despite the small sample size, due to the small number of initiating firms, the OLS results using the matched samples

\footnotetext{
${ }^{25}$ All models are calculated using the methodology found in Li and Mohanram (2014).

${ }^{26}$ Matching was attempted on multiple caliper distances, \# of neighbors, and other PSM settings to replicate results on the disclosers in Table 8, but no match was reasonably successful across the 6 matching variables.
} 
(panel B) are similar to those found in the entropy-balanced sample with a reduction in cost of capital for firms initating disclosure.

\subsection{Other Robustness Tests}

Industry analysis shows firms initiating disclosure have a high concentration in the "Eating and Drinking Places" (SIC 58xx) industry. I replicate model 1 of Table 6 excluding these firms and the results are similar. 


\section{CHAPTER SEVEN}

\section{CONCLUSION}

\subsection{Conclusion}

Salary expenses are unique costs due to their stability and salary expense disclosures may provide investors with information regarding company risk. Given this, the prevalent theory that assumes a negative relationship between a firm's disclosure of information and cost of capital may not hold. I examine firms who voluntarily disclose salary expenses and find evidence that the initial disclosure is associated with a lowered cost of capital for the firm, after controlling for the propensity to disclose. I also find disclosing firms with higher than industry median Salary have a lower cost of capital than similar firms, while other disclosing firms do not have a significantly different cost of capital than similar non-disclosing firms.

I examine whether the disclosure can provide investors with information regarding firm risk as theory suggests, and I show that higher cost stability (higher Salary) correlates with lower return volatility, which corresponds to my finding that investors charge more (higher AvgRI) for low Salary firms. I also show provide evidence that firms with higher salary expenses as a percentage of operating costs have more stable cost structures..

My results add to the disclosure literature by showing that salary disclosures provide valuable information to investors. This is seen through a decreased cost of capital for initial disclosers as well as a decreased cost of capital for disclosers who voluntarily disclose positive information. These results also provide evidence supporting the informational value of the recent mandatory employee pay disclosure rule (to the extent investors can use the disclosure to analyze cost structures), but adds doubt that a mandatory disclosure requirement was necessary. I also add to research that studies firm cost structures and risk. 


\section{REFERENCES}

Abarbanell, J. S., and B. J. Bushee. 1997. Fundamental Analysis, Future Earnings, and Stock Prices. Journal of Accounting Research 35 (1):1-24.

Alpern, R. L., and G. McGowan. 2001. Guide to Change of Control: Protecting Companies and Their Executives.

Amihud, Y., and H. Mendelson. 1986. Asset pricing and the bid-ask spread. Journal of Financial Economics 17 (2):223-249.

Awh, R. Y., and W. J. Primeaux. 1985. Managerial Discretion and Expense Preference Behavior. The Review of Economics and Statistics 67 (2):224-231.

Babenko, I., and R. Sen. 2015. Do nonexecutive employees have valuable information? Evidence from employee stock purchase plans. Management Science 62 (7):1878-1898.

Berk, J. B., R. Stanton, and J. Zechner. 2010. Human Capital, Bankruptcy, and Capital Structure. The Journal of Finance 65 (3):891-926.

Beyer, A., D. A. Cohen, T. Z. Lys, and B. R. Walther. 2010. The financial reporting environment: Review of the recent literature. Journal of Accounting and Economics 50 (2):296-343.

Bird, A., and S. A. Karolyi. 2016. Do Institutional Investors Demand Public Disclosure? The Review of Financial Studies 29 (12):3245-3277.

Card, D., A. Mas, E. Moretti, and E. Saez. 2012. Inequality at work: The effect of peer salaries on job satisfaction. American Economic Review 102 (6):2981-3003.

Chemmanur, T. J., Y. Cheng, and T. Zhang. 2013. Human capital, capital structure, and employee pay: An empirical analysis. Journal of Financial Economics 110 (2):478-502.

Chen, S., B. Miao, and T. Shevlin. 2015. A New Measure of Disclosure Quality: The Level of Disaggregation of Accounting Data in Annual Reports. Journal of Accounting Research 53 (5):1017-1054.

Claus, J., and J. Thomas. 2001. Equity Premia as Low as Three Percent? Evidence from Analysts' Earnings Forecasts for Domestic and International Stock Markets. The Journal of Finance 56 (5):1629-1666.

Depoers, F. 2000. A cost-benefit study of voluntary disclosure: some empirical evidence from French listed companies. European Accounting Review 9 (2):245-263.

Dhaliwal, D. S., H. S. Lee, M. Pincus, and L. B. Steele. 2017. Taxable Income and Firm Risk. The Journal of the American Taxation Association 39 (1):1-24.

Dhaliwal, D. S., O. Z. Li, A. Tsang, and Y. G. Yang. 2011. Voluntary nonfinancial disclosure and the cost of equity capital: The initiation of corporate social responsibility reporting. The Accounting Review 86 (1):59-100.

Diamond, D. W., and R. E. Verrecchia. 1991. Disclosure, Liquidity, and the Cost of Capital. The Journal of Finance 46 (4):1325-1359.

Faleye, O., E. Reis, and A. Venkateswaran. 2013. The determinants and effects of CEOemployee pay ratios. Journal of Banking and Finance 37:3258-3272.

Frydman, C., and R. E. Saks. 2010. Executive Compensation: A New View from a Long-Term Perspective, 1936-2005. The Review of Financial Studies 44 (5):2099-2138.

Gebhardt, W. R., C. M. C. Lee, and B. Swaminathan. 2001. Toward an Implied Cost of Capital. Journal of Accounting Research 39 (1):135-176. 
Grossman, S. J. 1981. The informational role of warranties and private disclosure about product quality. The Journal of Law and Economics 24 (3):461-483.

Hainmueller, J. 2012. Entropy Balancing for Causal Effects: A Multivariate Reweighting Method to Produce Balanced Samples in Observational Studies. Political Analysis 20 (1):25-46.

Hirsch, B. T., and D. A. Macpherson. 2003. Union membership and coverage database from the current population survey: Note. ILR Review 56 (2):349-354.

Hou, K., M. A. van Dijk, and Y. Zhang. 2012. The implied cost of capital: A new approach. Journal of Accounting and Economics 53 (3):504-526.

Kelly, K., and J. L. Seow. 2016. Investor Reactions to Company Disclosure of High CEO Pay and High CEO-to-Employee Pay Ratio: An Experimental Investigation. Journal of Management Accounting Research 28 (1):107-125.

Kothari, S. P., X. Li, and J. E. Short. 2009. The Effect of Disclosures by Management, Analysts, and Business Press on Cost of Capital, Return Volatility, and Analyst Forecasts: A Study Using Content Analysis. The Accounting Review 84 (5):1639-1670.

Lambert, R., C. Leuz, and R. E. Verrecchia. 2007. Accounting information, disclosure, and the cost of capital. Journal of Accounting Research 45 (2):385-420.

Lang, M., and R. Lundholm. 1993. Cross-sectional determinants of analyst ratings of corporate disclosures. Journal of Accounting Research 31 (2):246-271.

Leuz, C., and R. E. Verrecchia. 2000. The economic consequences of increased disclosure. Journal of Accounting Research:91-124.

Leuz, C., and P. D. Wysocki. 2016. The economics of disclosure and financial reporting regulation: Evidence and suggestions for future research. Journal of Accounting Research 54 (2):525-622.

Li, K. K., and P. Mohanram. 2014. Evaluating cross-sectional forecasting models for implied cost of capital. Review of Accounting Studies 19 (3):1152-1185.

Lin, H.-W., and M. F. McNichols. 1998. Underwriting relationships, analysts' earnings forecasts and investment recommendations. Journal of Accounting and Economics 25 (1):101-127.

McNichols, M., and P. C. O'Brien. 1997. Self-Selection and Analyst Coverage. Journal of Accounting Research 35:167-199.

Merton, R. C. 1987. A Simple Model of Capital Market Equilibrium with Incomplete Information. The Journal of Finance 42 (3):483-510.

Milgrom, P. R. 1981. Good news and bad news: Representation theorems and applications. The Bell Journal of Economics:380-391.

Monahan, S. J., and P. D. Easton. 2010. Evaluating accounting-based measures of expected returns: Easton and Monahan and Botosan and Plumlee redux. Available at SSRN 1592518.

Murphy, K. 2012. Executive Compensation: Where We Are, and How We Got There. Forthcoming in Handbook of the Economics of Finance:1 - 175.

Murphy, K. J. 1999. Chapter 38 Executive compensation. In Handbook of Labor Economics: Elsevier, 2485-2563.

Ohlson, J. A., and B. E. Juettner-Nauroth. 2005. Expected EPS and EPS growth as determinantsof value. Review of Accounting Studies 10 (2-3):349-365.

SEC. 2015. Pay Ratio Disclosure. Document Citation: 80 FR 50103. 
Skinner, D. J. 1994. Why Firms Voluntarily Disclose Bad News. Journal of Accounting Research 32 (1):38-60.

Titman, S. 1984. The effect of capital structure on a firm's liquidation decision. Journal of Financial Economics 13 (1):137-151.

Verrecchia, R. E. 1983. Discretionary disclosure. Journal of Accounting and Economics 5:179194.

Verrecchia, R. E. 2001. Essays on disclosure. Journal of Accounting and Economics 32:97-180.

Wells, H. 2010. "No Man can be Worth $\$ 1,000,000$ a Year": The Fight Over Executive Compensation in 1930s America. U. Richmond Law Review 44:689 - 769. 
Table 1 - Sample Statistics

\begin{tabular}{|c|c|c|c|c|c|c|}
\hline Panel A - Descriptive Statistics & count & mean & sd & p25 & p50 & p75 \\
\hline AvgRI & 83,384 & 0.081 & 0.052 & 0.052 & 0.069 & 0.093 \\
\hline VolDiscEmpPay & 83,384 & 0.073 & 0.261 & 0.000 & 0.000 & 0.000 \\
\hline DQ & 83,384 & 0.636 & 0.080 & 0.583 & 0.635 & 0.693 \\
\hline BTM & 83,384 & -0.749 & 0.844 & -1.231 & -0.684 & -0.187 \\
\hline MVE & 83,384 & 5.053 & 2.210 & 3.465 & 4.987 & 6.584 \\
\hline swbeta & 83,384 & 0.900 & 0.715 & 0.422 & 0.851 & 1.319 \\
\hline MktLev & 83,384 & 0.209 & 0.219 & 0.017 & 0.140 & 0.337 \\
\hline Restructure & 83,384 & 1.000 & 0.012 & 1.000 & 1.000 & 1.000 \\
\hline SI & 83,384 & 0.020 & 0.059 & 0.000 & 0.000 & 0.013 \\
\hline sdret & 83,384 & 0.143 & 0.086 & 0.086 & 0.123 & 0.175 \\
\hline NSEG & 83,384 & 0.450 & 0.623 & 0.000 & 0.000 & 1.099 \\
\hline Salary & 6,127 & 0.368 & 0.176 & 0.257 & 0.351 & 0.480 \\
\hline AvgPay & 5,945 & 3.419 & 0.790 & 2.964 & 3.560 & 3.933 \\
\hline IndConcentration & 83,384 & 0.003 & 0.003 & 0.002 & 0.002 & 0.004 \\
\hline CapRaised & 72,276 & 0.076 & 0.293 & -0.028 & 0.000 & 0.059 \\
\hline InstOwnership & 46,208 & 0.462 & 0.310 & 0.184 & 0.438 & 0.721 \\
\hline PCI & 82,953 & 0.505 & 0.381 & 0.216 & 0.414 & 0.705 \\
\hline Union & 83,384 & 0.120 & 0.101 & 0.041 & 0.091 & 0.157 \\
\hline AnalystDisp & 37,239 & 0.047 & 0.096 & 0.010 & 0.020 & 0.050 \\
\hline AnalystCoverage & 45,742 & 1.766 & 0.782 & 1.099 & 1.792 & 2.398 \\
\hline FcastError & 45,093 & 0.013 & 0.047 & 0.001 & 0.002 & 0.007 \\
\hline
\end{tabular}

Panel B - Test of Means for VolDiscEmpPay

\begin{tabular}{|c|c|c|c|c|c|}
\hline & \multicolumn{2}{|c|}{ Non-Disclosing Firm-Year Obs } & \multicolumn{2}{|c|}{ Disclosing Firm-Year Obs } & \multirow[b]{2}{*}{ MeanDiff } \\
\hline & $\mathrm{n}$ & Mean & $\mathrm{n}$ & Mean & \\
\hline AvgRI & 77,257 & 0.081 & 6,127 & 0.079 & $0.001 * *$ \\
\hline DQ & 77,257 & 0.637 & 6,127 & 0.627 & $0.009 * * *$ \\
\hline BTM & 77,257 & -0.748 & 6,127 & -0.761 & 0.013 \\
\hline MVE & 77,257 & 5.015 & 6,127 & 5.527 & $-0.512 * * *$ \\
\hline swbeta & 77,257 & 0.906 & 6,127 & 0.834 & $0.072 * * *$ \\
\hline MktLev & 77,257 & 0.207 & 6,127 & 0.238 & $-0.031 * * *$ \\
\hline Restructure & 77,257 & 1.000 & 6,127 & 1.000 & 0.000 \\
\hline si & 77,257 & 0.020 & 6,127 & 0.017 & $0.003 * * *$ \\
\hline sdret & 77,257 & 0.144 & 6,127 & 0.128 & $0.017 * * *$ \\
\hline NSEG & 77,257 & 0.449 & 6,127 & 0.456 & -0.007 \\
\hline IndConcentration & 77,257 & 0.003 & 6,127 & 0.004 & $-0.000 * * *$ \\
\hline CapRaised & 66,795 & 0.078 & 5,481 & 0.059 & $0.019 * * *$ \\
\hline InstOwnership & 42,703 & 0.459 & 3,505 & 0.499 & $-0.040 * * *$ \\
\hline PCI & 76,847 & 0.491 & 6,106 & 0.685 & $-0.194 * * *$ \\
\hline Union & 77,257 & 0.118 & 6,127 & 0.146 & $-0.028 * * *$ \\
\hline AnalystDisp & 34,329 & 0.047 & 2,910 & 0.047 & -0.000 \\
\hline AnalystCoverage & 42,395 & 1.745 & 3,347 & 2.028 & $-0.283 * * *$ \\
\hline FcastError & 41,787 & 0.013 & 3,306 & 0.010 & $-0.003 * * *$ \\
\hline
\end{tabular}

All continuous variables are winsorized at the $1 \%$ and $99 \%$ levels. Variable Descriptions are listed in Appendix A. Panel B tests the difference in averages for salary disclosers vs non-disclosers for the described variables. $\quad * * * \mathrm{p}<0.01, * * \mathrm{p}<0.05, * \mathrm{p}<0.01$ 
Table 2 - Pearson Correlations

\begin{tabular}{|c|c|c|c|c|c|c|c|c|c|c|c|c|c|c|c|c|c|c|c|c|}
\hline Variables & (1) & (2) & (3) & (4) & (5) & (6) & (7) & (8) & (9) & (10) & (11) & (12) & (13) & (14) & (15) & (16) & (17) & (18) & (19) & (20) \\
\hline (1) AvgRI & 1.000 & & & & & & & & & & & & & & & & & & & \\
\hline (2) DQ & -0.225 & 1.000 & & & & & & & & & & & & & & & & & & \\
\hline (3) BTM & 0.281 & 0.023 & 1.000 & & & & & & & & & & & & & & & & & \\
\hline (4) MVE & -0.595 & 0.310 & -0.365 & 1.000 & & & & & & & & & & & & & & & & \\
\hline (5) swbeta & -0.268 & 0.175 & -0.216 & 0.378 & 1.000 & & & & & & & & & & & & & & & \\
\hline (6) MktLev & 0.226 & -0.163 & 0.397 & -0.194 & -0.135 & 1.000 & & & & & & & & & & & & & & \\
\hline (7) Restructure & 0.005 & -0.018 & 0.002 & -0.011 & -0.005 & -0.002 & 1.000 & & & & & & & & & & & & & \\
\hline (8) si & 0.088 & -0.018 & -0.034 & -0.072 & 0.022 & 0.010 & 0.001 & 1.000 & & & & & & & & & & & & \\
\hline (9) sdret & 0.224 & -0.191 & -0.109 & -0.318 & 0.157 & -0.016 & 0.003 & 0.152 & 1.000 & & & & & & & & & & & \\
\hline (10) NSEG & -0.122 & 0.197 & 0.064 & 0.318 & 0.056 & 0.109 & -0.014 & -0.015 & -0.153 & 1.000 & & & & & & & & & & \\
\hline (11) Salary & -0.170 & 0.063 & 0.010 & 0.064 & 0.007 & -0.031 & . & -0.022 & -0.083 & -0.082 & 1.000 & & & & & & & & & \\
\hline (12) AvgPay & -0.118 & 0.049 & -0.033 & 0.289 & 0.100 & 0.020 & . & 0.027 & -0.067 & 0.198 & 0.206 & 1.000 & & & & & & & & \\
\hline (13) IndConcentration & 0.048 & -0.091 & 0.115 & -0.065 & -0.084 & 0.166 & -0.005 & -0.037 & -0.030 & -0.001 & -0.156 & -0.148 & 1.000 & & & & & & & \\
\hline (14) CapRaised & -0.040 & -0.178 & -0.205 & -0.021 & 0.110 & -0.008 & 0.003 & 0.011 & 0.200 & -0.088 & -0.044 & -0.105 & -0.016 & 1.000 & & & & & & \\
\hline (15) InstOwnership & -0.463 & 0.392 & -0.215 & 0.713 & 0.335 & -0.119 & -0.018 & -0.021 & -0.253 & 0.244 & -0.008 & 0.300 & -0.038 & -0.045 & 1.000 & & & & & \\
\hline (16) PCI & 0.085 & -0.141 & 0.135 & -0.037 & -0.120 & 0.199 & 0.006 & -0.034 & -0.095 & 0.016 & -0.068 & -0.155 & 0.032 & -0.116 & -0.090 & 1.000 & & & & \\
\hline (17) Union & 0.121 & -0.142 & 0.074 & -0.058 & -0.071 & 0.165 & 0.001 & -0.027 & -0.058 & 0.022 & -0.047 & 0.194 & -0.020 & 0.004 & -0.154 & 0.115 & 1.000 & & & \\
\hline (18) AnalystDisp & 0.060 & -0.106 & 0.126 & -0.071 & -0.013 & 0.197 & 0.000 & 0.118 & 0.048 & 0.001 & -0.047 & 0.132 & 0.008 & 0.035 & -0.074 & 0.107 & 0.122 & 1.000 & & \\
\hline (19) AnalystCoverage & -0.393 & 0.112 & -0.308 & 0.761 & 0.254 & -0.121 & -0.005 & -0.045 & -0.196 & 0.112 & -0.044 & 0.146 & -0.038 & -0.024 & 0.497 & 0.019 & -0.030 & -0.028 & 1.000 & \\
\hline (20) FcastError & 0.233 & -0.102 & 0.135 & -0.268 & -0.068 & 0.198 & 0.000 & 0.211 & 0.188 & -0.044 & -0.037 & -0.026 & 0.012 & 0.010 & -0.200 & 0.041 & 0.040 & 0.427 & -0.226 & 1.000 \\
\hline
\end{tabular}

Variable Descriptions are listed in Appendix A. 
Table 3 - Count of Firms Initiating and Discontinuing Disclosure by Year

\begin{tabular}{|lcccccccccccc|}
\hline Year & $\mathbf{1 9 8 4}$ & $\mathbf{1 9 8 5}$ & $\mathbf{1 9 8 6}$ & $\mathbf{1 9 8 7}$ & $\mathbf{1 9 8 8}$ & $\mathbf{1 9 8 9}$ & $\mathbf{1 9 9 0}$ & $\mathbf{1 9 9 1}$ & $\mathbf{1 9 9 2}$ & $\mathbf{1 9 9 3}$ & $\mathbf{1 9 9 4}$ & $\mathbf{1 9 9 5}$ \\
\hline NewVol & 5 & 9 & 6 & 16 & 16 & 7 & 15 & 9 & 2 & 9 & 14 & 12 \\
StopVol & 19 & 17 & 10 & 16 & 17 & 16 & 11 & 18 & 7 & 9 & 11 & 21 \\
& & & & & & & & & & & & \\
Year & $\mathbf{1 9 9 6}$ & $\mathbf{1 9 9 7}$ & $\mathbf{1 9 9 8}$ & $\mathbf{1 9 9 9}$ & $\mathbf{2 0 0 0}$ & $\mathbf{2 0 0 1}$ & $\mathbf{2 0 0 2}$ & $\mathbf{2 0 0 3}$ & $\mathbf{2 0 0 4}$ & $\mathbf{2 0 0 5}$ & $\mathbf{2 0 0 6}$ & $\mathbf{2 0 0 7}$ \\
\hline NewVol & 10 & 8 & 2 & 3 & 3 & 5 & 5 & 8 & 4 & 5 & 3 & 7 \\
StopVol & 13 & 17 & 12 & 11 & 9 & 5 & 6 & 4 & 5 & 0 & 3 & 0 \\
& & & & & & & & & & & & \\
Year & $\mathbf{2 0 0 8}$ & $\mathbf{2 0 0 9}$ & $\mathbf{2 0 1 0}$ & $\mathbf{2 0 1 1}$ & $\mathbf{2 0 1 2}$ & $\mathbf{2 0 1 3}$ & $\mathbf{2 0 1 4}$ & $\mathbf{2 0 1 5}$ & $\mathbf{2 0 1 6}$ & $\mathbf{2 0 1 7}$ & & Total \\
\hline NewVol & 3 & 5 & 4 & 5 & 4 & 1 & 2 & 2 & 2 & 1 & & $\mathbf{2 1 2}$ \\
StopVol & 2 & 0 & 0 & 1 & 5 & 0 & 0 & 3 & 1 & 1 & & $\mathbf{2 7 0}$ \\
& & & & & & & & & & & & \\
\hline
\end{tabular}


Table 4-Salary Expense Disclosure and a Firm's Cost of Capital

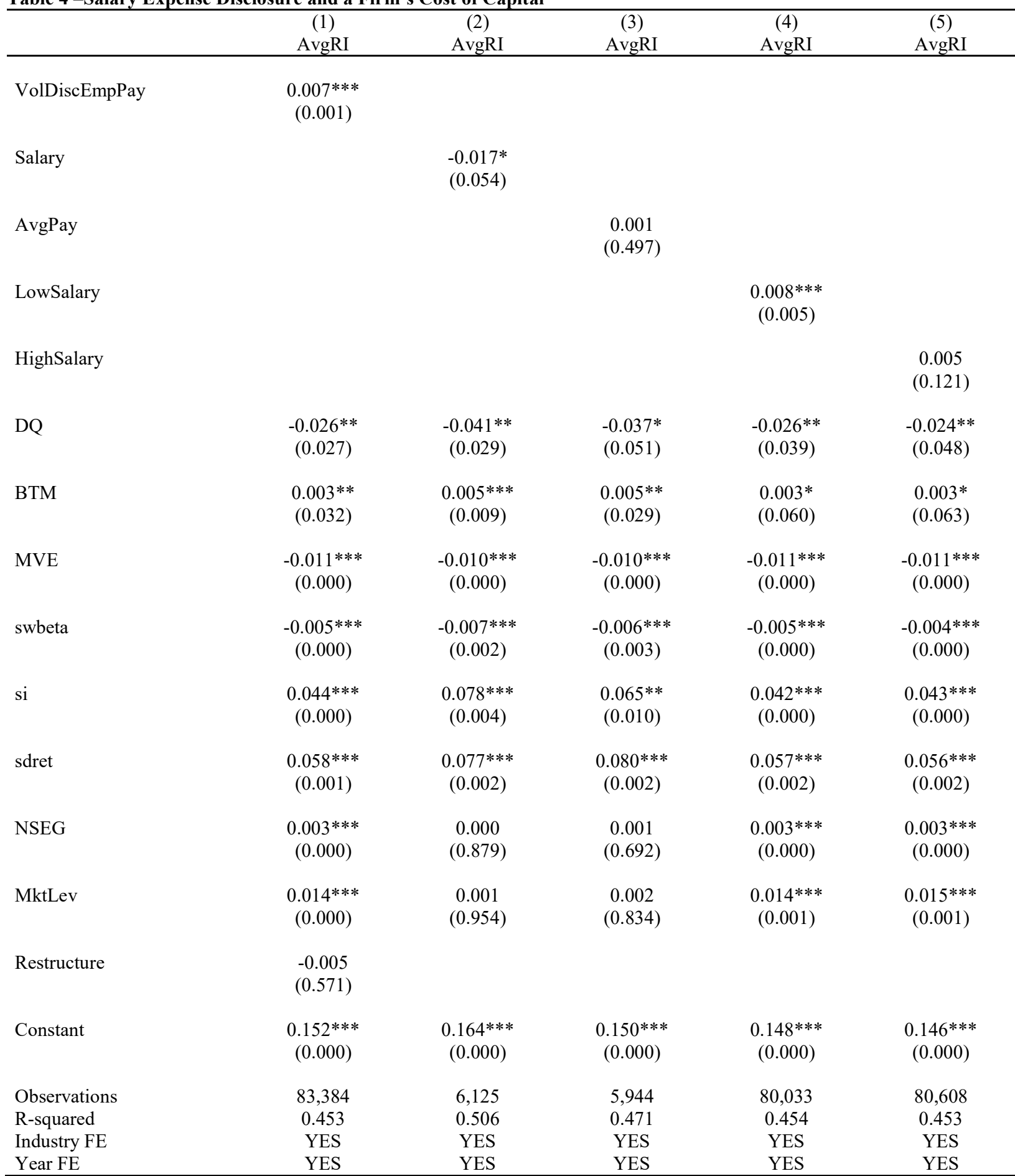

Model 1 examines the effects of disclosure on a firm's cost of capital (AvgRI). Model 1 shows that disclosure positively associates with AvgRI. Models 2 and 3 examine whether investors value the cost structure information or employee pay information respectively from the firm's salary disclosure as measured by its effect on a firm's cost of capital (AvgRI). Given the results from Models 2 and 3, Models 4 and 5 examine whether the positive correlation between the disclosure and a firm's cost of capital is spread across all firms or dependent upon the level of Salary. (Models 4 and 5 split the disclosers into Low (model 4) and High (model 5) Salary disclosers.) All continuous variables are winsorized at the $1 \%$ and $99 \%$ levels. Variable Descriptions are listed in Appendix A. Robust p-values (two-tailed) are in parentheses (clustered at industry and year level).

$* * * \mathrm{p}<0.01, * * \mathrm{p}<0.05, * \mathrm{p}<0.1$ 
(1)

Predicted Sign

VolDiscEmpPay

MVE

(?)

$0.447 * * *$

(0.000)

BTM

$0.398 * * *$

(0.000)

DQ

$-1.223 * *$

(0.015)

AvgRI

(+)

$3.367 * *$

(0.046)

ROA

(-)

0.276

(0.396)

IndConcentration

(+)

64.310

(0.635)

MktLev

(+)

$-0.116$

(0.522)

CapRaised

(+)

$-0.200$

(0.127)

InstOwnership

(+)

$-0.013$

(0.932)

PCI

(+)

$1.019 * * *$

Union

$6.298 * * *$

(0.000)

AnalystDisp

$+)$

0.084

(0.788)

AnalystCoverage

(+)

0.070

(0.331)

FcastError

(+)

$-1.193$

(0.334)

Constant

Observations

24,553

Area under ROC curve

Industry Indicators

YES

Year Indicators

YES

This table examines potential determinants of the disclosure of salary expenses using a logit model. All continuous variables are winsorized at the $1 \%$ and $99 \%$ levels. Variable Descriptions are listed in Appendix A. Robust p-values (two-tailed) are in parentheses. $\quad * * * \mathrm{p}<0.01, * * \mathrm{p}<0.05, * \mathrm{p}<0.1$ 
Table 6 - Effect of Disclosure on Cost of Capital - Balance Sample

\begin{tabular}{|c|c|c|c|}
\hline Panel A - Treated vs Control & Treated & Control & Diff \\
\hline $\mathrm{MVE}_{\mathrm{t}}$ & 5.536 & 5.536 & 0.000 \\
\hline $\mathrm{DQ}_{\mathrm{t}}$ & 0.628 & 0.628 & 0.000 \\
\hline $\operatorname{AvgRI}_{t}$ & 0.079 & 0.079 & 0.000 \\
\hline $\mathrm{BTM}_{\mathrm{t}}$ & -0.762 & -0.762 & 0.000 \\
\hline $\mathrm{PCI}_{t}$ & 0.685 & 0.685 & 0.000 \\
\hline Union $_{\mathrm{t}}$ & 0.146 & 0.146 & 0.000 \\
\hline Panel B - Regression Results & $\begin{array}{c}(1) \\
\text { AvgRI }\end{array}$ & $\begin{array}{c}(2) \\
\text { AvgRI }\end{array}$ & $\begin{array}{c}(3) \\
\text { AvgRI }\end{array}$ \\
\hline VolDiscEmpPay & $\begin{array}{c}-0.000 \\
(0.556)\end{array}$ & $\begin{array}{c}0.001 \\
(0.283)\end{array}$ & $\begin{array}{c}-0.002 * * \\
(0.034)\end{array}$ \\
\hline DQ & $\begin{array}{c}-0.011 * * * \\
(0.000)\end{array}$ & $\begin{array}{c}-0.011 * * * \\
(0.000)\end{array}$ & $\begin{array}{c}-0.011 * * * * \\
(0.000)\end{array}$ \\
\hline BTM & $\begin{array}{c}-0.045 * * * \\
(0.000)\end{array}$ & $\begin{array}{c}-0.053 * * * \\
(0.000)\end{array}$ & $\begin{array}{c}-0.036^{* * *} \\
(0.000)\end{array}$ \\
\hline MVE & $\begin{array}{c}0.004^{* * *} \\
(0.000)\end{array}$ & $\begin{array}{c}0.005^{* * *} \\
(0.000)\end{array}$ & $\begin{array}{c}0.004 * * * \\
(0.000)\end{array}$ \\
\hline swbeta & $\begin{array}{c}-0.007 * * * \\
(0.000)\end{array}$ & $\begin{array}{c}-0.007 * * * \\
(0.000)\end{array}$ & $\begin{array}{c}-0.007^{* * *} * \\
(0.000)\end{array}$ \\
\hline si & $\begin{array}{c}-0.012 * * * \\
(0.000)\end{array}$ & $\begin{array}{c}-0.013 * * * \\
(0.000)\end{array}$ & $\begin{array}{c}-0.012 * * * \\
(0.001)\end{array}$ \\
\hline sdret & $\begin{array}{c}0.066^{* * *} \\
(0.000)\end{array}$ & $\begin{array}{c}0.060 * * * \\
(0.000)\end{array}$ & $\begin{array}{c}0.065 * * * \\
(0.000)\end{array}$ \\
\hline NSEG & $\begin{array}{c}0.087 * * * \\
(0.000)\end{array}$ & $\begin{array}{c}0.092 * * * \\
(0.000)\end{array}$ & $\begin{array}{c}0.080 * * * \\
(0.000)\end{array}$ \\
\hline MktLev & $\begin{array}{c}0.001 * * * \\
(0.002)\end{array}$ & $\begin{array}{c}0.001 * * \\
(0.027)\end{array}$ & $\begin{array}{c}0.001 * \\
(0.085)\end{array}$ \\
\hline Restructure & $\begin{array}{c}0.002 \\
(0.512)\end{array}$ & $\begin{array}{l}-0.001 \\
(0.788)\end{array}$ & $\begin{array}{c}0.005 \\
(0.139)\end{array}$ \\
\hline Constant & $\begin{array}{c}0.184 * * * \\
(0.000)\end{array}$ & $\begin{array}{c}0.197 * * * \\
(0.000)\end{array}$ & $\begin{array}{c}0.178 * * * \\
(0.000)\end{array}$ \\
\hline $\begin{array}{l}\text { Observations } \\
\text { R-squared } \\
\text { Industry FE } \\
\text { Year FE }\end{array}$ & $\begin{array}{c}82,953 \\
0.462 \\
\text { YES } \\
\text { YES }\end{array}$ & $\begin{array}{c}79,607 \\
0.466 \\
\text { YES } \\
\text { YES }\end{array}$ & $\begin{array}{c}80,193 \\
0.450 \\
\text { YES } \\
\text { YES }\end{array}$ \\
\hline
\end{tabular}

This table examines whether the results from Table 4, Model 1 after controlling for a company's propensity to disclose using the significant determinants found in Table 7 utilizing an entropy-balanced sample. Panel A shows the success of the balancing using a test of means of the treated vs control observations. Panel B - Model 1 shows the results of OLS regressions utilizing the balanced sample. Models 2 and 3 split the treated sample into Low (model 2) and High (model 3) Salary disclosers. All continuous variables are winsorized at the 1\% and 99\% levels. Variable Descriptions are listed in Appendix A. P-values (two-tailed) are in parentheses. $* * * \mathrm{p}<0.01, * * \mathrm{p}<0.05, * \mathrm{p}<0.1$ 
Table 7 - Why does Salary matter? Salary as Indicators of Risk

\begin{tabular}{|c|c|c|c|c|c|c|}
\hline & $\begin{array}{c}(1) \\
\text { sdret }\end{array}$ & $\begin{array}{c}(2) \\
\text { sdret }\end{array}$ & $\begin{array}{c}(3) \\
\text { sdret }\end{array}$ & $\begin{array}{c}(4) \\
\text { sdOpex }\end{array}$ & $\begin{array}{c}5) \\
\text { sdOpex } \\
\end{array}$ & $\begin{array}{c}(6) \\
\text { sdOpex }\end{array}$ \\
\hline Salary & $\begin{array}{c}-0.121^{* * *} \\
(0.005)\end{array}$ & $\begin{array}{c}-0.212 * * \\
(0.029)\end{array}$ & $\begin{array}{l}-0.048 \\
(0.309)\end{array}$ & $\begin{array}{c}-1.193 * * * \\
(0.002)\end{array}$ & $\begin{array}{c}-2.172 * * * \\
(0.005)\end{array}$ & $\begin{array}{c}-1.280^{* * *} \\
(0.009)\end{array}$ \\
\hline BTM & $\begin{array}{l}-0.002 \\
(0.655)\end{array}$ & $\begin{array}{l}-0.002 \\
(0.727)\end{array}$ & $\begin{array}{l}-0.007 \\
(0.278)\end{array}$ & $\begin{array}{c}0.400 * * * \\
(0.000)\end{array}$ & $\begin{array}{c}0.434 * * * \\
(0.000)\end{array}$ & $\begin{array}{c}0.383^{* * *} * \\
(0.000)\end{array}$ \\
\hline MVE & $\begin{array}{c}-0.028 * * * \\
(0.000)\end{array}$ & $\begin{array}{c}-0.025^{* * *} \\
(0.000)\end{array}$ & $\begin{array}{c}-0.033 * * * \\
(0.000)\end{array}$ & $\begin{array}{c}0.505 * * * \\
(0.000)\end{array}$ & $\begin{array}{c}0.515 * * * \\
(0.000)\end{array}$ & $\begin{array}{c}0.487 * * * \\
(0.000)\end{array}$ \\
\hline lev & $\begin{array}{c}0.042 * * \\
(0.033)\end{array}$ & $\begin{array}{c}0.009 \\
(0.738)\end{array}$ & $\begin{array}{c}0.059 * * \\
(0.029)\end{array}$ & $\begin{array}{c}1.542 * * * \\
(0.000)\end{array}$ & $\begin{array}{c}1.503 * * * \\
(0.000)\end{array}$ & $\begin{array}{c}1.606^{* * *} * \\
(0.000)\end{array}$ \\
\hline CFlow_sd & $\begin{array}{c}0.025 \\
(0.566)\end{array}$ & $\begin{array}{c}0.076 \\
(0.141)\end{array}$ & $\begin{array}{l}-0.064 \\
(0.401)\end{array}$ & $\begin{array}{c}1.301 * * * \\
(0.002)\end{array}$ & $\begin{array}{l}0.819^{*} \\
(0.076)\end{array}$ & $\begin{array}{c}2.467 * * * \\
(0.003)\end{array}$ \\
\hline RetSkew & $\begin{array}{l}-0.002 \\
(0.752)\end{array}$ & $\begin{array}{l}-0.008 \\
(0.292)\end{array}$ & $\begin{array}{c}0.001 \\
(0.950)\end{array}$ & & & \\
\hline vol_mean & $\begin{array}{c}0.000 * * \\
(0.023)\end{array}$ & $\begin{array}{c}0.000 * * * \\
(0.000)\end{array}$ & $\begin{array}{c}0.000 \\
(0.277)\end{array}$ & & & \\
\hline retx_sum & $\begin{array}{c}0.060 * * * \\
(0.000)\end{array}$ & $\begin{array}{c}0.053 * * * \\
(0.000)\end{array}$ & $\begin{array}{c}0.062 * * * \\
(0.000)\end{array}$ & & & \\
\hline Constant & $\begin{array}{c}0.310^{* * *} \\
(0.000)\end{array}$ & $\begin{array}{c}0.307 * * * \\
(0.000)\end{array}$ & $\begin{array}{c}0.312 * * * \\
(0.000)\end{array}$ & $\begin{array}{c}1.380 * * * \\
(0.000)\end{array}$ & $\begin{array}{c}1.489^{* * *} \\
(0.001)\end{array}$ & $\begin{array}{c}1.586 * * * \\
(0.002)\end{array}$ \\
\hline Observations & 2,951 & 1,318 & 1,575 & 4,391 & 1,983 & 2,340 \\
\hline R-squared & 0.668 & 0.691 & 0.688 & 0.938 & 0.948 & 0.938 \\
\hline Firm FE & YES & YES & YES & YES & YES & YES \\
\hline Year FE & YES & YES & YES & YES & YES & YES \\
\hline
\end{tabular}

This table examines whether Salary disclosures can help provide explanation of a firm's risk beyond typical explanatory risk variables. Model 1 examines whether Salary helps explain a firm's return volatility. Models 2 and 3 split the treated sample into Low (model 2) and High (model 3) Salary disclosers. Models 4 - 6 examine whether a firm's Salary associates with the volatility of operating expense, splitting the treated sample into Low (model 5) and High (model 6) Salary disclosers.. All continuous variables are winsorized at the $1 \%$ and $99 \%$ levels. Variable Descriptions are listed in Appendix A. Robust p-values (two-tailed) are in parentheses (clustered at firm and year level).

$* * * \mathrm{p}<0.01, * * \mathrm{p}<0.05, * \mathrm{p}<0.1$ 


\begin{tabular}{|c|c|c|}
\hline & Predicted Sign & $\begin{array}{c}(1) \\
\text { NewVol } \\
\end{array}$ \\
\hline $\mathrm{MVE}_{\mathrm{t}-1}$ & $(?)$ & $\begin{array}{l}-0.360 \\
(0.110)\end{array}$ \\
\hline BTM $_{t-1}$ & $(-)$ & $\begin{array}{c}-0.056 \\
(0.846)\end{array}$ \\
\hline DQ & $(?)$ & $\begin{array}{l}-4.942 \\
(0.149)\end{array}$ \\
\hline $\operatorname{AvgRI}_{t-1}$ & $(+)$ & $\begin{array}{c}1.208 \\
(0.869)\end{array}$ \\
\hline $\mathrm{ROA}_{\mathrm{t}-1}$ & $(-)$ & $\begin{array}{c}-1.590 * \\
(0.092)\end{array}$ \\
\hline IndConcentration $_{\mathrm{t}-1}$ & $(+)$ & $\begin{array}{c}-113.112 \\
(0.639)\end{array}$ \\
\hline MktLev $_{\mathrm{t}-1}$ & $(+)$ & $\begin{array}{c}0.624 \\
(0.520)\end{array}$ \\
\hline CapRaised ${ }_{t-1}$ & $(+)$ & $\begin{array}{c}0.717 \\
(0.210)\end{array}$ \\
\hline InstOwnership & $(+)$ & $\begin{array}{l}-0.372 \\
(0.669)\end{array}$ \\
\hline $\mathrm{PCI}_{\mathrm{t}-1}$ & $(+)$ & $\begin{array}{l}1.229 * * \\
(0.015)\end{array}$ \\
\hline Union $_{\mathrm{t}-1}$ & $(-)$ & $\begin{array}{c}-18.433 * * * \\
(0.006)\end{array}$ \\
\hline AnalystDisp $_{\mathrm{t}-1}$ & $(+)$ & $\begin{array}{l}-0.993 \\
(0.630)\end{array}$ \\
\hline AnalystCoverage $_{t-1}$ & $(+)$ & $\begin{array}{c}0.826 * * \\
(0.029)\end{array}$ \\
\hline FcastError $_{\mathrm{t}-1}$ & $(+)$ & $\begin{array}{c}-20.367 \\
(0.265)\end{array}$ \\
\hline Constant & & $\begin{array}{l}-0.355 \\
(0.896)\end{array}$ \\
\hline $\begin{array}{l}\text { Observations } \\
\text { Area under ROC curve } \\
\text { Industry Indicators } \\
\text { Year Indicators }\end{array}$ & & $\begin{array}{c}8,911 \\
.880 \\
\text { YES } \\
\text { YES }\end{array}$ \\
\hline
\end{tabular}

This table examines potential determinants of the decision to initiate disclosure of salary expenses using a logit model. All continuous variables are winsorized at the 1\% and 99\% levels. Variable Descriptions are listed in Appendix A. Robust $\mathrm{p}$-values (two-tailed) are in parentheses. $\quad * * * \mathrm{p}<0.01, * * \mathrm{p}<0.05, * \mathrm{p}<0.1$ 
Table 9 - Effect of Initiating Disclosure on Cost of Capital - Balanced Sample

\begin{tabular}{|c|c|c|c|}
\hline Panel A - Treated vs Control & Treated & Control & Diff \\
\hline $\mathrm{ROA}_{\mathrm{t}-1}$ & -0.006 & -0.006 & 0.000 \\
\hline AnalystCoverage $_{\mathrm{t}}$ & 1.793 & 1.793 & 0.000 \\
\hline $\mathrm{PCI}_{\mathrm{t}-1}$ & 0.622 & 0.621 & 0.001 \\
\hline Union $\mathrm{t}-1$ & 0.131 & 0.131 & 0.000 \\
\hline Panel B - Regression Results & $\begin{array}{c}(1) \\
\Delta \text { AvgRI } \\
\end{array}$ & $\begin{array}{c}(2) \\
\Delta \text { AvgRI } \\
\end{array}$ & $\begin{array}{c}(3) \\
\Delta \text { AvgRI } \\
\end{array}$ \\
\hline NewVol & $\begin{array}{c}-0.004 * * \\
(0.017)\end{array}$ & $\begin{array}{c}-0.003 * * * \\
(0.005)\end{array}$ & $\begin{array}{c}-0.005 * * \\
(0.039)\end{array}$ \\
\hline$\Delta \mathrm{DQ}$ & $\begin{array}{c}-0.038^{*} \\
(0.051)\end{array}$ & $\begin{array}{c}-0.011 * * \\
(0.048)\end{array}$ & $\begin{array}{c}-0.030 * \\
(0.085)\end{array}$ \\
\hline$\triangle \mathrm{BTM}$ & $\begin{array}{c}0.009 * * * \\
(0.000)\end{array}$ & $\begin{array}{c}0.009 * * * \\
(0.000)\end{array}$ & $\begin{array}{c}0.007 * * * \\
(0.001)\end{array}$ \\
\hline$\triangle \mathrm{MVE}$ & $\begin{array}{c}-0.005^{* *} \\
(0.033)\end{array}$ & $\begin{array}{c}-0.004 * * * \\
(0.006)\end{array}$ & $\begin{array}{c}-0.004 * * \\
(0.014)\end{array}$ \\
\hline$\Delta$ swbeta & $\begin{array}{c}0.002 \\
(0.130)\end{array}$ & $\begin{array}{c}0.003 * * * \\
(0.000)\end{array}$ & $\begin{array}{l}-0.000 \\
(0.483)\end{array}$ \\
\hline$\Delta$ Restructure & $\begin{array}{c}0.002 \\
(0.297)\end{array}$ & $\begin{array}{c}0.002 \\
(0.289)\end{array}$ & $\begin{array}{c}0.001 \\
(0.378)\end{array}$ \\
\hline$\Delta \mathrm{si}$ & $\begin{array}{c}0.030 * * * \\
(0.000)\end{array}$ & $\begin{array}{c}0.031 * * * \\
(0.000)\end{array}$ & $\begin{array}{c}0.023 * * * \\
(0.000)\end{array}$ \\
\hline$\Delta$ sdret & $\begin{array}{c}0.015 \\
(0.208)\end{array}$ & $\begin{array}{c}-0.004 \\
(0.271)\end{array}$ & $\begin{array}{c}0.010 \\
(0.288)\end{array}$ \\
\hline$\triangle \mathrm{NSEG}$ & $\begin{array}{l}-0.001 \\
(0.398)\end{array}$ & $\begin{array}{c}0.000 \\
(0.469)\end{array}$ & $\begin{array}{l}0.002 * \\
(0.080)\end{array}$ \\
\hline$\Delta$ MktLev & $\begin{array}{c}0.017 * * \\
(0.036)\end{array}$ & $\begin{array}{c}0.024 * * * \\
(0.000)\end{array}$ & $\begin{array}{c}0.029 * * * \\
(0.000)\end{array}$ \\
\hline Constant & $\begin{array}{c}-0.002 \\
(0.247)\end{array}$ & $\begin{array}{c}-0.005^{* *} \\
(0.013)\end{array}$ & $\begin{array}{l}-0.002 \\
(0.281)\end{array}$ \\
\hline $\begin{array}{l}\text { Observations } \\
\text { R-squared } \\
\text { Industry FE } \\
\text { Year FE }\end{array}$ & $\begin{array}{c}31,268 \\
0.364 \\
\text { YES } \\
\text { YES }\end{array}$ & $\begin{array}{c}31,237 \\
0.352 \\
\text { YES } \\
\text { YES } \\
\end{array}$ & $\begin{array}{c}31,234 \\
0.337 \\
\text { YES } \\
\text { YES } \\
\end{array}$ \\
\hline
\end{tabular}

This table examines whether firms receive a lowered cost of capital from their decision to disclose after controlling for the propensity to initiate disclosure utilizing an entropy-balanced sample. Panel A shows the success of the matches using a test of means of the treated vs control observations. Panel B shows the results of OLS regressions utilizing the controlled samples. The dependent variable and control variables in Panel B are measured as the change from the prior year's value. Model 1 utilizes the full balanced sample. Models 2 and 3 split the treated sample into Low (model 2) and High (model 3) Salary disclosers. All continuous variables are winsorized at the $1 \%$ and $99 \%$ levels. Variable Descriptions are listed in Appendix A. P-values (onetailed) are in parentheses.

$* * * \mathrm{p}<0.01, * * \mathrm{p}<0.05, * \mathrm{p}<0.1$ 
Table 10 - Salary Levels for Firms Initiating Disclosure

\begin{tabular}{|c|c|c|c|c|}
\hline & $\begin{array}{c}(1) \\
\text { Salary }\end{array}$ & $\begin{array}{c}(2) \\
\text { Salary } \\
\end{array}$ & $\begin{array}{c}(3) \\
\text { Salary }\end{array}$ & $\begin{array}{c}(4) \\
\text { Salary }\end{array}$ \\
\hline NewVolFirm & $\begin{array}{l}-0.022 \\
(0.103)\end{array}$ & & & \\
\hline NewVol2 & & $\begin{array}{c}-0.034 * * * \\
(0.001)\end{array}$ & & \\
\hline NewVol $=1(T$ vs $T+1)$ & & & $\begin{array}{c}-0.008^{* *} \\
(0.025)\end{array}$ & \\
\hline NewVol=1 $(\mathrm{T}$ vs $\mathrm{T}+2)$ & & & & $\begin{array}{c}-0.029 * * \\
(0.027)\end{array}$ \\
\hline MVE & $\begin{array}{c}0.013 * * * \\
(0.001)\end{array}$ & $\begin{array}{c}0.013 * * * \\
(0.000)\end{array}$ & $\begin{array}{c}-0.022 * \\
(0.093)\end{array}$ & $\begin{array}{c}-0.035^{* *} \\
(0.017)\end{array}$ \\
\hline AvgSales & $\begin{array}{c}-0.147^{* *} \\
(0.043)\end{array}$ & $\begin{array}{c}-0.157 * * \\
(0.037)\end{array}$ & $\begin{array}{c}-0.058^{* * *} \\
(0.000)\end{array}$ & $\begin{array}{c}-0.014 \\
(0.704)\end{array}$ \\
\hline MTB & $\begin{array}{c}-0.003 * * * \\
(0.001)\end{array}$ & $\begin{array}{c}-0.003 * * * \\
(0.000)\end{array}$ & $\begin{array}{l}-0.001 \\
(0.296)\end{array}$ & $\begin{array}{c}-0.005 * * * \\
(0.007)\end{array}$ \\
\hline MktLev & $\begin{array}{l}-0.030 \\
(0.107)\end{array}$ & $\begin{array}{l}-0.025 \\
(0.292)\end{array}$ & $\begin{array}{l}-0.057 \\
(0.182)\end{array}$ & $\begin{array}{c}-0.147 * * * \\
(0.003)\end{array}$ \\
\hline PCI & $\begin{array}{c}0.040 \\
(0.167)\end{array}$ & $\begin{array}{c}0.022 \\
(0.428)\end{array}$ & $\begin{array}{l}-0.051 \\
(0.374)\end{array}$ & $\begin{array}{l}-0.050 \\
(0.371)\end{array}$ \\
\hline EBIT & $\begin{array}{l}-0.052 \\
(0.172)\end{array}$ & $\begin{array}{l}-0.036 \\
(0.301)\end{array}$ & $\begin{array}{c}0.157 * * \\
(0.042)\end{array}$ & $\begin{array}{c}0.026 \\
(0.766)\end{array}$ \\
\hline EBIT_sd & $\begin{array}{l}-0.077 \\
(0.378)\end{array}$ & $\begin{array}{l}-0.109 \\
(0.241)\end{array}$ & $\begin{array}{c}0.101 \\
(0.321)\end{array}$ & $\begin{array}{c}0.069 \\
(0.470)\end{array}$ \\
\hline Constant & $\begin{array}{c}0.342 * * * \\
(0.000)\end{array}$ & $\begin{array}{c}0.336 * * * \\
(0.000)\end{array}$ & $\begin{array}{c}0.493 * * * \\
(0.000)\end{array}$ & $\begin{array}{c}0.619 * * * \\
(0.000)\end{array}$ \\
\hline $\begin{array}{l}\text { Observations } \\
\text { R-squared } \\
\text { Industry FE } \\
\text { Year FE }\end{array}$ & $\begin{array}{c}4,594 \\
0.505 \\
\text { YES } \\
\text { YES }\end{array}$ & $\begin{array}{l}5,895 \\
0.477 \\
\text { YES } \\
\text { YES }\end{array}$ & $\begin{array}{c}270 \\
0.990 \\
\text { YES } \\
\text { YES }\end{array}$ & $\begin{array}{c}220 \\
0.984 \\
\text { YES } \\
\text { YES }\end{array}$ \\
\hline
\end{tabular}

Model 1 examines the Salary levels of firms initiating disclosure compared to firms that disclose in all years they appear in the sample. Model 2 examines Salary level for the initial disclosure of NewVolFirms compared to all other disclosure observations. Models 3 and 4 examine the salary level for the initial disclosure of NewVolfirms compared to future year's disclosure ( $\mathrm{T}+1$ and $\mathrm{T}+2$ respectively). All continuous variables are winsorized at the $1 \%$ and $99 \%$ levels. Variable Descriptions are listed in Appendix A. Robust p-values (two-tailed) are in parentheses (clustered at industry and year level). $* * * \mathrm{p}<0.01, * *$ $\mathrm{p}<0.05, * \mathrm{p}<0.1$ 
Table 11 - Multiple ICC Regressions for Robustness

\begin{tabular}{|c|c|c|c|c|c|}
\hline & $\begin{array}{c}(1) \\
\text { AvgRI }\end{array}$ & $\begin{array}{c}(2) \\
\text { glsicc }\end{array}$ & $\begin{array}{l}(3) \\
\text { cticc }\end{array}$ & $\begin{array}{c}(4) \\
\text { ojicc }\end{array}$ & $\begin{array}{c}(5) \\
\text { pegicc }\end{array}$ \\
\hline VolDiscEmpPay & $\begin{array}{c}0.007 * * * \\
(0.001)\end{array}$ & $\begin{array}{c}0.005 * * * \\
(0.002)\end{array}$ & $\begin{array}{c}0.008 * * * \\
(0.000)\end{array}$ & $\begin{array}{c}0.005^{* *} \\
(0.010)\end{array}$ & $\begin{array}{c}0.003 * * \\
(0.024)\end{array}$ \\
\hline DQ & $\begin{array}{c}-0.031 * * * \\
(0.004)\end{array}$ & $\begin{array}{c}-0.064 * * * \\
(0.000)\end{array}$ & $\begin{array}{l}-0.012 \\
(0.376)\end{array}$ & $\begin{array}{c}-0.051^{* * *} \\
(0.000)\end{array}$ & $\begin{array}{c}-0.050 * * * \\
(0.000)\end{array}$ \\
\hline BTM & $\begin{array}{c}0.004 * * \\
(0.012)\end{array}$ & $\begin{array}{c}0.002 * * \\
(0.025)\end{array}$ & $\begin{array}{c}0.006^{* * *} \\
(0.005)\end{array}$ & $\begin{array}{c}0.021 * * * \\
(0.000)\end{array}$ & $\begin{array}{c}0.022 * * * \\
(0.000)\end{array}$ \\
\hline MVE & $\begin{array}{c}-0.011 * * * \\
(0.000)\end{array}$ & $\begin{array}{c}-0.018^{* * *} \\
(0.000)\end{array}$ & $\begin{array}{c}-0.007 * * * \\
(0.000)\end{array}$ & $\begin{array}{c}-0.012 * * * \\
(0.000)\end{array}$ & $\begin{array}{c}-0.011 * * * \\
(0.000)\end{array}$ \\
\hline swbeta & $\begin{array}{c}-0.005 * * * \\
(0.000)\end{array}$ & $\begin{array}{c}-0.003 * * * \\
(0.002)\end{array}$ & $\begin{array}{c}-0.005^{* * *} * \\
(0.002)\end{array}$ & $\begin{array}{l}-0.001 \\
(0.587)\end{array}$ & $\begin{array}{c}0.000 \\
(0.746)\end{array}$ \\
\hline Restructure & $\begin{array}{l}-0.006 \\
(0.548)\end{array}$ & $\begin{array}{l}-0.019 \\
(0.167)\end{array}$ & $\begin{array}{l}-0.006 \\
(0.587)\end{array}$ & $\begin{array}{c}0.003 \\
(0.795)\end{array}$ & $\begin{array}{c}0.009 \\
(0.119)\end{array}$ \\
\hline si & $\begin{array}{c}0.045 * * * \\
(0.000)\end{array}$ & $\begin{array}{c}0.065 * * * \\
(0.000)\end{array}$ & $\begin{array}{l}0.025^{*} \\
(0.051)\end{array}$ & $\begin{array}{c}0.166 * * * \\
(0.000)\end{array}$ & $\begin{array}{c}0.142 * * * \\
(0.000)\end{array}$ \\
\hline sdret & $\begin{array}{c}0.059 * * * \\
(0.001)\end{array}$ & $\begin{array}{c}0.095 * * * \\
(0.000)\end{array}$ & $\begin{array}{c}0.024 \\
(0.228)\end{array}$ & $\begin{array}{c}0.086^{* * * *} \\
(0.000)\end{array}$ & $\begin{array}{c}0.094 * * * \\
(0.000)\end{array}$ \\
\hline NSEG & $\begin{array}{c}0.003 * * * \\
(0.000)\end{array}$ & $\begin{array}{c}0.002 * * * \\
(0.000)\end{array}$ & $\begin{array}{c}0.003 * * * \\
(0.000)\end{array}$ & $\begin{array}{l}0.001 * \\
(0.052)\end{array}$ & $\begin{array}{c}0.000 \\
(0.902)\end{array}$ \\
\hline Constant & $\begin{array}{c}0.160^{* * * *} \\
(0.000)\end{array}$ & $\begin{array}{c}0.212 * * * \\
(0.000)\end{array}$ & $\begin{array}{c}0.145^{* * * *} \\
(0.000)\end{array}$ & $\begin{array}{c}0.207 * * * \\
(0.000)\end{array}$ & $\begin{array}{c}0.182 * * * \\
(0.000)\end{array}$ \\
\hline $\begin{array}{l}\text { Observations } \\
\text { R-squared } \\
\text { Industry FE } \\
\text { Year FE }\end{array}$ & $\begin{array}{c}83,693 \\
0.451 \\
\text { YES } \\
\text { YES }\end{array}$ & $\begin{array}{c}102,545 \\
0.591 \\
\text { YES } \\
\text { YES }\end{array}$ & $\begin{array}{c}88,792 \\
0.303 \\
\text { YES } \\
\text { YES }\end{array}$ & $\begin{array}{c}77,186 \\
0.452 \\
\text { YES } \\
\text { YES }\end{array}$ & $\begin{array}{c}79,055 \\
0.482 \\
\text { YES } \\
\text { YES }\end{array}$ \\
\hline
\end{tabular}

This table examines whether this paper's results are robust to other measures of cost of capital. Model 1 recreates the results from Table 6, model 1 for reference. Models 2 and 3 use the individual residual income implied cost of capital measures that combine to form AvgRI based on Gebhardt et al. (2001) and Claus and Thomas (2001)'s models. Model 4's implied cost of capital measure is based on Ohlson and Juettner-Nauroth (2005) and Model 5 uses a simplified price earnings growth model ( $\mathrm{Li}$ and Mohanram 2014). Samples for the 4 individual models are not subject to the constraint of the availability of the AvgRI measures to additionally ensure results are not due to this constraint. All continuous variables are winsorized at the $1 \%$ and $99 \%$ levels. Variable Descriptions are listed in Appendix A. Robust p-values (two-tailed) are in parentheses (clustered at firm and year level).

${ }^{* * *} \mathrm{p}<0.01,{ }^{* *} \mathrm{p}<0.05,{ }^{*} \mathrm{p}<0.1$ 
$\underline{\text { Table } 12 \text { - Effect of Initiating Disclosure on Cost of Capital - PSM Sample }}$

\begin{tabular}{|c|c|c|c|}
\hline Panel A - Treated vs Control & Treated & Control & Diff \\
\hline $\operatorname{ROA}_{t-1}$ & 0.031 & 0.018 & 0.013 \\
\hline Analyst Coverage $_{\mathrm{t}}$ & 1.763 & 1.712 & 0.051 \\
\hline $\mathrm{PCI}_{\mathrm{t}-1}$ & 0.623 & 0.612 & 0.011 \\
\hline Union $_{\mathrm{t}-1}$ & 0.114 & 0.111 & 0.003 \\
\hline Panel B - Regression Results & $\begin{array}{c}(1) \\
\text { AvgRI } \\
\end{array}$ & $\begin{array}{c}(2) \\
\text { AvgRI } \\
\end{array}$ & $\begin{array}{c}(3) \\
\text { AvgRI } \\
\end{array}$ \\
\hline VolDiscEmpPay & $\begin{array}{c}-0.011 * \\
(0.051)\end{array}$ & $\begin{array}{l}-0.004 \\
(0.205)\end{array}$ & $\begin{array}{c}-0.024 * * \\
(0.018)\end{array}$ \\
\hline DQ & $\begin{array}{c}-0.065^{*} \\
(0.052)\end{array}$ & $\begin{array}{l}-0.043 \\
(0.143)\end{array}$ & $\begin{array}{c}-0.017 \\
(0.395)\end{array}$ \\
\hline BTM & $\begin{array}{c}-0.030 \\
(0.109)\end{array}$ & $\begin{array}{c}-0.027 * \\
(0.079)\end{array}$ & $\begin{array}{l}-0.029 \\
(0.157)\end{array}$ \\
\hline MVE & $\begin{array}{c}-0.033^{*} \\
(0.039)\end{array}$ & $\begin{array}{c}-0.033^{* *} \\
(0.023)\end{array}$ & $\begin{array}{c}-0.029 * \\
(0.077)\end{array}$ \\
\hline swbeta & $\begin{array}{c}0.001 \\
(0.397)\end{array}$ & $\begin{array}{c}0.002 \\
(0.332)\end{array}$ & $\begin{array}{l}-0.001 \\
(0.430)\end{array}$ \\
\hline si & $\begin{array}{l}-0.015 \\
(0.341)\end{array}$ & $\begin{array}{l}-0.010 \\
(0.392)\end{array}$ & $\begin{array}{c}-0.005 \\
(0.458)\end{array}$ \\
\hline sdret & $\begin{array}{c}0.021 \\
(0.240)\end{array}$ & $\begin{array}{c}0.015 \\
(0.351)\end{array}$ & $\begin{array}{c}0.054 \\
(0.104)\end{array}$ \\
\hline NSEG & $\begin{array}{c}-0.002 \\
(0.432)\end{array}$ & $\begin{array}{c}-0.002 \\
(0.407)\end{array}$ & $\begin{array}{c}0.001 \\
(0.453)\end{array}$ \\
\hline MktLev & $\begin{array}{l}-0.013 \\
(0.334)\end{array}$ & $\begin{array}{c}-0.031 \\
(0.204)\end{array}$ & $\begin{array}{c}-0.021 \\
(0.318)\end{array}$ \\
\hline \multicolumn{4}{|l|}{ Restructure } \\
\hline Constant & $\begin{array}{c}0.008 * * \\
(0.050)\end{array}$ & $\begin{array}{c}0.005 * * \\
(0.039)\end{array}$ & $\begin{array}{c}0.009 * * \\
(0.022)\end{array}$ \\
\hline $\begin{array}{l}\text { Observations } \\
\text { R-squared } \\
\text { Industry FE } \\
\text { Year FE }\end{array}$ & $\begin{array}{l}185 \\
0.500 \\
\text { YES } \\
\text { YES }\end{array}$ & $\begin{array}{l}152 \\
0.635 \\
\text { YES } \\
\text { YES }\end{array}$ & $\begin{array}{l}144 \\
0.542 \\
\text { YES } \\
\text { YES }\end{array}$ \\
\hline
\end{tabular}

This table recreates results from Table 8 using propensity score matched samples. Panel A shows the success of the balancing using a test of means of the treated vs control observations. Panel B - Model 1 shows the results of OLS regressions utilizing the matched sample. Models 2 and 3 split the treated sample into Low (model 2) and High (model 3) Salary disclosers. All continuous variables are winsorized at the 1\% and $99 \%$ levels. Variable Descriptions are listed in Appendix A. Robust p-values (one-tailed) are in parentheses (clustered at firm and year level).

$* * * \mathrm{p}<0.01, * * \mathrm{p}<0.05,{ }^{*} \mathrm{p}<0.1$ 


\section{Appendix A - Variable Definitions}

\begin{tabular}{|c|c|}
\hline Variables & Description \\
\hline AvgPay & Salary expense (xlr) divided by the number of employees (emp) \\
\hline AvgRI & $\begin{array}{l}\text { Firm's ex ante implied cost of capital measure, as recommended by (Li and } \\
\text { Mohanram 2014) }\end{array}$ \\
\hline AvgSales & Revenue per employee (revt/emp) divided by 1,000 \\
\hline AnalystDisp & $\begin{array}{l}\text { Standard deviation of the one year ahead analyst forecasts for a firm in a } \\
\text { year }\end{array}$ \\
\hline AnalystCoverage & Natural log of ( 1 plus of the number of analysts covering the firm) \\
\hline BTM & Natural log of a firm's book to market ratio (ceq/MVE). \\
\hline CapRaised & $\begin{array}{l}\text { The amount of capital raised by a firm in that year from Compustat (sstk- } \\
\text { prstkc+dltis-dltr) scaled by the beginning of the year's total assets (at). }\end{array}$ \\
\hline CFlow_sd & $\begin{array}{l}\text { The standard deviation of a firm's operating cash flows (oancf) scaled by } \\
\text { the firm's beginning of the year's assets (at) for the past } 5 \text { years. }\end{array}$ \\
\hline DQ & $\begin{array}{l}\text { A measure of a firm's overall disclosure quality as per Chen et al. (2015), } \\
\text { excluding the effect of disclosing salary expense. }\end{array}$ \\
\hline EBIT & A firm's earnings before interest and taxes, scaled by total assets (ebit/at) \\
\hline EBIT_sd & The standard deviation of a firm's EBIT for the past 5 years. \\
\hline FcastĒror & $\begin{array}{l}\text { Absolute value of difference between the average analyst EPS forecast and } \\
\text { the actuals, scaled by the beginning of the year's price per share (prcc f) }\end{array}$ \\
\hline HighSalary & $\begin{array}{l}\text { Indicator variable equal to one if a firm discloses salary expense higher than } \\
\text { the median for that industry, and } 0 \text { if the firm does not disclose in that year. }\end{array}$ \\
\hline IndConcentration & $\begin{array}{l}\text { Herfindahl-Hirschman Index of a firm's industry measure by total revenues } \\
\text { (Compustat revt). }\end{array}$ \\
\hline InstOwnership & Total Institutional ownership as a percentage of shares outstanding. \\
\hline Lev & A firm's debt to asset ratio from Compustat $(\mathrm{dltt}+\mathrm{dlc}) /(\mathrm{at})$ \\
\hline LowSalary & $\begin{array}{l}\text { Indicator variable equal to one if a firm discloses salary expense less than } \\
\text { or equal to the median for that industry, and } 0 \text { if the firm does not disclose } \\
\text { in that year. }\end{array}$ \\
\hline MktLev & $\begin{array}{l}\text { Firm's debt to Market Value of Assets ratio from Compustat } \\
(\mathrm{dltt}+\mathrm{dlc}) /\left(\mathrm{dltt}+\mathrm{dlc}+\mathrm{csho}^{*} \text { prcc_f }\right)\end{array}$ \\
\hline MTB & $\begin{array}{l}\text { A firm's market value of equity (MVE) divided by the book value of equity } \\
\text { from Compustat (ceq). }\end{array}$ \\
\hline MVE & Natural log of a firm's market value of equity (csho*prcc_f). \\
\hline NewVol & $\begin{array}{l}\text { Indicator variable equal to } 1 \text { if a concerned firm initiates disclosure of salary } \\
\text { expense (Compustat xlr) in that year after not disclosing the prior year, and } \\
0 \text { for all firm observations for firms that do not ever disclose in my sample. } \\
\text { (Used for treatment/control group for propensity to disclose.) }\end{array}$ \\
\hline NewVol2 & $\begin{array}{l}\text { Indicator variable equal to } 1 \text { if a concerned firm initiates disclosure of salary } \\
\text { expense (Compustat xlr) in that year after not disclosing the prior year } \\
(\text { NewVol=1), and } 0 \text { for all non-NewVolFirm observations that contain a } \\
\text { salary expense disclosure. }\end{array}$ \\
\hline NewVolFirm & $\begin{array}{l}\text { Indicator variable equal to } 1 \text { if a concerned firm initiates disclosure } \\
\text { (Compustat xlr) at any point in my sample, and } 0 \text { if the firm disclosed for } \\
\text { all of their firm-year observations in my sample. }\end{array}$ \\
\hline NSEG & Natural log of the number of a firm's business segments in that year. \\
\hline
\end{tabular}




\section{Appendix A - cont.}

\begin{tabular}{ll}
\hline Variables & Description \\
\hline PCI & A firm's physical capital intensity from Compustat (ppegt/at) \\
ROA & A firm's return on assets: the ratio of income before extraordinary items \\
divided by total assets at the beginning of each year (Compustat ib/att-1) \\
Restructure & Indicator variable equal to one if a firm has restructuring costs (Compustat \\
& rcp) in a year, 0 otherwise. \\
Ret_sd & Standard deviation of the firm's daily returns for the prior year. \\
RetSkew & Skewness of the firm's daily returns for the prior year. \\
Retx_sum & Sum of a firm's daily returns (excluding dividends) over the prior year. \\
Salary & Compustat salary expense (xlr) as a percentage of total operating expense \\
& (xopr) \\
Sdret & Standard deviation of a firm's prior year's monthly returns. \\
sdOpex & Standard deviation of a firm's Operating expenses for the past 5 years \\
Si & (logged) \\
Swbeta & Special Items (Compustat spi) scaled by total assets (at) \\
Union & CAPM beta measured as per the Scholes-Williams method. \\
& The percentage of the employees covered by a collective bargaining \\
agr_mean & Macpherson (2003). Data is available at www.unionstats.com \\
VolDiscEmpPay & Average volume of shares traded daily for the prior year (scaled by 1,000) \\
& Indicator variable equal to 1 if a concerned firm discloses salary expense \\
(Compustat xlr) in that year, and 0 otherwise.
\end{tabular}

